Georgia State University

ScholarWorks @ Georgia State University

$1-2-2012$

\title{
Combat Exposure and Migraine Headache: Evidence from Exogenous Deployment Assignment
}

\author{
Resul Cesur \\ University of Connecticut, cesur@business.uconn.edu \\ Joseph J. Sabia \\ San Diego State University, jsabia@mail.sdsu.edu \\ Erdal Tekin \\ Georgia State University, tekin@gsu.edu
}

Follow this and additional works at: https://scholarworks.gsu.edu/uwrg_workingpapers

\section{Recommended Citation}

Cesur, Resul; Sabia, Joseph J.; and Tekin, Erdal, "Combat Exposure and Migraine Headache: Evidence from Exogenous Deployment Assignment" (2012). UWRG Working Papers. 43.

https://scholarworks.gsu.edu/uwrg_workingpapers/43

This Article is brought to you for free and open access by the Usery Workplace Research Group at ScholarWorks @ Georgia State University. It has been accepted for inclusion in UWRG Working Papers by an authorized administrator of ScholarWorks @ Georgia State University. For more information, please contact scholarworks@gsu.edu. 
Working Paper 12-1-2

January 2012

\section{Combat Exposure and}

Migraine Headache: Evidence

from Exogenous Deployment

Assignment

Resul Cesur

University of Connecticut

Joseph J. Sabia

San Diego State University \& U.S. Military Academy

\section{Erdal Tekin}

Georgia State University 


\title{
Combat Exposure and Migraine Headache: Evidence from Exogenous Deployment Assignment ${ }^{*}$
}

\author{
Resul Cesur \\ University of Connecticut \\ Finance Department \\ School of Business \\ 2100 Hillside Road Unit 1041 \\ Storrs, CT 06269-1041 \\ Email: cesur@business.uconn.edu
}

\author{
Joseph J. Sabia \\ San Diego State University \& U.S. Military Academy \\ Department of Economics \\ 5500 Campanile Drive \\ San Diego, CA 92182-4485 \\ Email: jsabia@mail.sdsu.edu \\ Erdal Tekin \\ Georgia State University, IZA and NBER \\ Department of Economics \\ Andrew Young School of Public Policy \\ Email: tekin@gsu.edu
}

\section{January 2012}

\footnotetext{
* An earlier draft of this paper was written while Sabia was an assistant professor at the United States Military Academy. We thank Chandler McCellan for excellent research assistance. This research uses data from Add Health, a program project designed by J. Richard Udry, Peter S. Bearman, and Kathleen Mullan Harris, and funded by a grant P01-HD31921 from the National Institute of Child Health and Human Development, with cooperative funding from 17 other agencies. Special acknowledgment is due Ronald R. Rindfuss and Barbara Entwisle for assistance in the original design. Persons interested in obtaining data files from Add Health should contact Add Health, Carolina Population Center, 123 W. Franklin Street, Chapel Hill, NC 27516-2524 (http://www.cpc.unc.edu/addhealth/contract.html).
} 


\title{
Combat Exposure and Migraine Headache: Evidence from Exogenous Deployment Assignment
}

\begin{abstract}
Migraine headache is a growing problem for U.S. servicemen deployed in the Global War on Terrorism and has been linked to substantial negative socioeconomic consequences. However, there has been no comprehensive examination of the relationship between combat exposure and migraine headache or its stress-related triggers. Using data drawn from the National Longitudinal Study of Adolescent Health, we exploit exogenous variation in deployment assignment to estimate the effect of combat exposure on migraine headache. We find that those deployed to a combat zone with enemy firefight are at substantially increased risk for migraine headache relative to those deployed to non-combat zones outside the United States or to combat zones without enemy firefight. This relationship is robust to controls for pre-deployment migraine status and is largest for those serving in the Army in the post-9/11 period. We find that combat-induced sleep disorders, stress-related psychological problems, and physical injuries in combat explain 47 to 60 percent of the relationship between combat exposure and migraine headache.
\end{abstract}

Keywords: migraine headache, combat exposure, sleep disruption 
"Migraine, and headaches in general, are important health concerns for the military services because they often have sudden, unpredictable onsets; are relatively common among young adults; are potentially debilitating; and are operationally and medically costly." -Christopher Martin, Armed Forces Health Surveillance Center, 2008

\section{Introduction}

A recent study from the Rand Corporation reported that nearly 320,000 U.S. troops deployed to Iraq and Afghanistan in the Global War on Terrorism have experienced traumatic brain injuries (TBI) (Tanilian and Jaycox, 2008). However, many medical experts believe this is a lower-bound estimate because of a strong stigma associated with seeking treatment for traumatic brain injury (Simpson et al., 2000) and because mild TBI is often undetected by M.R.I. technology (Brody et al., 2011). One observable indicator of rising cases of hidden head trauma among combat veterans is the increased prevalence of migraine headache, an ailment linked by military health professionals to mild TBI (Martin 2008; Theeler et al. 2008, 2009, 2010; Vargas 2009).

Between 2001 and 2007, migraine diagnoses among those in the U.S. Army increased by nearly 60 percent (Martin, 2008). A 2008 study of active-duty Army servicemen returning from deployment in Iraq found that 17.4 percent of males and 34.9 percent of females screened positive for migraine headache (Theeler et al., 2008). These prevalence rates are 3 to 4 times larger than that observed for civilians (Stewart et al., 1992; Lipton et al., 2001; Lipton et al., 2007). This difference is especially stark when one factors in that a history of migraine headache problems may disqualify an individual from military service (Department of Defense Directives 6130.3 and 6130.4). Of course, hidden head trauma is but one explanation for rising cases of migraine headache among combat veterans. Combat-related psychological stress and other stress-induced health ailments—such as sleep disorders—may also induce migraine headache. 
Understanding the causes of migraine headache has become increasingly important to economists, who have documented its substantial adverse educational and labor market consequences. Recent studies of civilian populations have found that migraine headache is associated with less human capital acquisition (Rees and Sabia, 2011; Sabia and Rees, 2011), lower earnings (Rees and Sabia, 2010), reduced productivity at work (Osterhaus et al., 1992; Stewart et al., 2003), and a greater number of missed workdays (Lipton et al., 2007). A similar pattern of evidence has emerged in the military medical literature. Theeler et al. (2008) find that soldiers who screen positive for migraine headache are more likely to call in sick from work and are more likely to face on-the-job productivity impairments than their non-migraineur counterparts in the months following deployment.

While several recent studies have linked deployment to Iraq and Afghanistan to a greater risk of migraine headache, most simply describe the prevalence of migraine headache among military personnel (Theeler et al., 2008, 2009; Martin, 2008). Two recent studies have identified control groups for active duty deployed soldiers: civilians (Vargas, 2009) and military personnel who remain stateside (Jankosky et al., 2011). While descriptively informative, each of the control groups used in these studies may be problematic if unobservable factors correlated with active duty service are associated with physical and psychological health (Cesur et al., 2011). No study of which we are aware has identified a plausibly exogenous source of variation in combat exposure to identify the effect of combat exposure on migraine headache, nor has any study been able to empirically examine the mechanisms through which combat might affect migraine headache.

Using data drawn from the National Longitudinal Study of Adolescent Health, we examine the relationship between combat exposure and the probability of migraine headache. 
We exploit the fact that soldiers' deployment assignments across and within combat zones are plausibly exogenous to individual and family background characteristics to identify the causal effect of combat on migraine headache. Our results suggest that soldiers deployed to combat zones with enemy firefight are at substantially increased risk of migraine headache relative to their counterparts deployed to non-combat zones outside the United States and to combat zones without enemy firefight. These results are robust to controlling for pre-deployment migraine headache and are largest for those soldiers serving in the Army in the post-9/11 period. We also find that combat exposure is positively related to sleep disorders, stress, and physical injurythree of the triggers for migraine headache. Our findings suggest that combat-induced sleep disorders, psychological stress, and physical injury can explain 47 to 60 percent of the estimated relationship between combat exposure and migraine headache.

\section{Background}

While tension headache is the most common type of primary headache, migraine headache has received the most attention from both medical scholars (Breslau and Rasmussen, 2001) and economists (Rees and Sabia, 2011; Sabia and Rees, 2011) due to its substantial adverse health and human capital effects. The Mayo Clinic characterizes migraine headache in the following manner:

"A migraine headache can cause intense throbbing or pulsing in one area of the head and is commonly accompanied by nausea, vomiting, and extreme sensitivity to light and sound. Migraine attacks can cause significant pain for hours to days and be so severe that all you can think about is finding a dark, quiet place to lie down.” (Mayo Clinic, 2011)

Migraine headache is typically distinguished from common tension headache by the nausea and sensitivity to light that accompany attacks (Martin, 2008; p. 6) as well as the longer duration of 
symptoms, typically 4 to 72 hours (Mayo Clinic, 2011; Headache Classification Subcommittee of the IHS 2004, p. 31). However, the symptoms of each type of headache are often hard to distinguish given that many migraineurs also suffer from tension headache (Kaniecki, 2002; Lyngberg et al. 2005).

Migraine attacks are often proceeded by aura, which include "visual phenomena, such as seeing various shapes, bright spots, or flashes of light, vision loss, [a feeling of] pins and needle sensations in an arm or leg, [and] speech or language problems" (Mayo Clinic, 2011). While scientists have recently identified a genetic link to migraine headache (Chasman et al. 2011; Verneri et al., 2010; Lafrenière, 2010; Russell and Olesen, 1995; Ulrich et al., 1999; De Fuso et al., 2003; de Vries et al., 2007; Sabia and Rees, 2011), several environmental triggers for migraine attacks have been identified in the literature: increased stress at work or home, sleep disruption, foods, sensory stimuli changes, environmental changes, intense physical exertion, heat, noise, and hormonal changes (Mayo Clinic, 2011; Kaniecki, 2002). Migraine headache is most common when individuals are between the ages of 25 and 55, when people are generally in their most productive years (Hazard et al., 2009).

The causes and consequences of migraine headache have been studied extensively in civilian populations (Kaniecki, 2002; Stewart et al., 2003; Hazard et al., 2009), with economists recently documenting its adverse schooling and labor market consequences (Rees and Sabia, 2011; Sabia and Rees, 2011; Rees and Sabia, 2011), and estimating its substantial costs (over $\$ 13$ billion in 1997 dollars) on employers due to missed work days and diminished productivity (Hu et al., 1999). However, migraine headache has not been widely studied among military populations despite the fact that the triggers for migraine headache are particularly intense among those serving in combat. Understanding whether particular types of military service 
increase the risk for migraine headache is, therefore, critical not only to obtaining accurate estimates of the full short-run health costs of combat, but also in understanding potential longerrun labor market consequences of combat-induced migraine for those soldiers that transition to civilian life.

There is evidence that the prevalence of migraine headache has grown substantially during the Global War on Terrorism. Martin (2008) documents rising rates of migraine headache across all branches of the Armed Forces between 2001 and 2007, with the largest increase observed for those serving in the Army. The incidence of first migraine headache diagnosis rose among active-duty Army men from 6.60 per 1,000 person-years in 2001 to 10.45 per 1,000 person-years in 2007; during the same period, the incidence of first-time migraine diagnosis among Army women rose from 30.2 to 40.5 per 1,000 person-years (Martin, 2008). ${ }^{1}$ Among all branches, the rate of increase among active-duty Airmen was the smallest.

The growing concern with the migraine headache have led medical researchers to label this health condition "a significant medical problem in [Armed] service personnel due to the strenuous work environment and exposure to known stressors [that]...can include sleep deprivation, physical exertion, change in environmental conditions, emotional stress, and dehydration" (Seifert and Evans, 2010; p. 3). Migraines have been found to account for nearly 75 percent of post-traumatic headaches observed in soldiers (Theeler et al., 2008; Vargas, 2009) and have been linked to blast- or explosion-induced mild TBI (Vargas, 2009; Seifert and Evans, 2010; Theeler and Erickson, 2009).

\footnotetext{
${ }^{1}$ Evidence that females as opposed to males are more likely to suffer from migraine headache is consistent with evidence on civilian populations. Rees and Sabia (2011) note that approximately 20 percent of adult women in the United States report having had at least one migraine headache in the past year, compared to 5 to 6 percent of adult men (Stewart et al., 1992; Lipton et al., 2001; Lipton et al., 2007).
} 
While there is evidence that combat exposure is associated with a higher risk of migraine headache, much of the evidence on which this conclusion is based is descriptive in nature. Theeler et al. (2008) examined a brigade of 2,726 U.S. Army soldiers following a one-year combat tour to Iraq and found that 17.4 percent of male and 34.9 percent of female respondents screened positive for migraine headache; Theeler and Erickson (2009) examined a sample of returning combat troops who received specialized medical services for headaches and found that approximately half had "a history of mild head trauma" (p. 529), with "head trauma temporally associated with either the onset of headache or the worsening of pre-existing headaches" ( $\mathrm{p}$. 529); and Theeler et al. (2009) examined a small sample of U.S. Army soldiers with recurring headache and found that the most commonly reported headache triggers included "environmental factors (74\%), stress (67\%), consumption-related factors (60\%), and fatigue-related factors (57\%)" (p. 790). There is also descriptive evidence that those who screen positive for migraine headache are more likely to miss work more frequently than their counterparts without such severe diagnoses (Theeler et al., 2008) and that these effects may persist a year after deployment.

While intriguing and informative, these studies linking migraine headache to combat deployment are limited because most of them rely on convenience samples that lack an appropriate counterfactual control group with plausibly exogenous assignment. One recent study (Jankosky et al., 2011) has provided the first suggestive evidence that combat deployment may be associated with migraine headache. Using data from the Millennium Cohort Study, Jankosky et al. (2011) compare migraine headache among those deployed to combat zones with migraine headache among non-deployers and find that deployment is associated with a substantial increase in the probability of a migraine diagnosis. However, non-deployed Reservists or National Guardsmen and active-duty non-deployable soldiers may differ on many individual-level 
unobservables related to health (Department of the Army AR 614-30, 2010; Cesur et al., 2011) or human capital (Hirsch and Mehay, 2003), thus potentially contaminating estimates of the migraine effects of combat exposure.

No study of which we are aware has used longitudinal data and information on deployment assignment within combat zones to identify the causal effect of combat exposure on the probability of migraine headache. ${ }^{2}$ Moreover, no study has empirically explored how three important triggers of migraine headache - combat-induced sleep disruption, stress, and combatrelated physical injuries - mediate the relationship between combat exposure and migraine headache. We contribute to the literature by using longitudinal data on health and exploiting plausibly exogenous variation in overseas deployment assignment to estimate (i) the effects of combat exposure on migraine headache as well as its triggers, and (ii) the degree to which combat-induced sleep disorders, stress, and physical injuries can explain the relationship between combat exposure and migraine headache.

\section{Data and Measures}

Our analysis uses data drawn from the National Longitudinal Study of Adolescent Health (Add Health), a nationally representative school-based survey of $7^{\text {th }}$ through $12^{\text {th }}$ graders in 19941995. In the baseline in-home survey (Wave I), a total of 20,745 respondents ages 11 to 21 were asked a wide set of questions related to physical health, mental health, health behaviors, academic performance, family background, peer and familial relationships, and attitudes toward health, family, and their futures. A parent and a school administrator questionnaire were also

\footnotetext{
${ }^{2}$ While there is little work exploring the relationship between combat exposure and migraine headache, the relationship between combat exposure and other stress-related health outcomes has been the subject of a number of recent studies in the economics literature (Angrist et al., 2010; Hearst et al., 1986; Bedard and Deschenes, 2004; Dobkin and Shabani, 2009; Edwards and MacLean, 2010; Cesur, Sabia, and Tekin, 2011; Gade and Wenger, 2011).
} 
administered at baseline. Approximately one year later (1996), a follow-up survey was conducted (Wave II), with many of the same in-home questionnaire items repeated. A second follow-up interview (Wave III) was conducted in 2001 when respondents were between the ages of 18 and 28, and a third follow-up interview (Wave IV) was conducted in 2007-2008 to15,701 of the original Add Health respondents who were then between the ages 24 and 33 (see Harris et al., 2008 for a discussion of the Add Health data collection strategy).

The Add Health data are useful for the purposes of this paper because they (i) contain a relatively large sample of deployed active-duty military servicemen $(\mathrm{N}=592)$ at the time of the Wave IV survey, (ii) contain information on whether overseas deployment assignment was to a non-combat zone $(\mathrm{N}=153)$, a combat zone without enemy firefight $(\mathrm{N}=248)$, or a combat zone where respondents saw enemy firefight $(\mathrm{N}=191)$, and (iii) contain information on migraine status and a number of triggers of migraine headache, including sleep disorders and stress. Furthermore, because the survey is longitudinal in nature and spans back to adolescence, we have information on the respondent's migraine status prior to any military deployment. We restrict our analysis sample to 902 respondents who started the military service after Wave I Survey and provided non-missing information on branch of service, migraine status and combat zone service length. One limitation of this survey, however, is that we measure health and military outcomes when respondents are young adults ages 24 to 33 . Thus, care should be taken in generalizing results to older populations.

We measure combat service in the United States Armed Forces using respondents' reports of active duty service and deployment assignment at Wave IV. Specifically, the Add Health respondents were asked: 
In which components of the military have you served? (Possible answers: None, Active Duty, Reserves, National Guard)

Following this questionnaire item, respondents were then asked about deployment experiences:

Was your military service in the US, outside the US, or both?

What is the total amount of time you (have) served in a combat zone?

Finally, among those deployed to combat zones, we can measure whether the respondent was exposed to combat by whether they had ever "engaged the enemy in firefight."

In the Add Health, 935 respondents reported active duty military service ${ }^{3}$ and 175 respondents reported non-active duty service exclusively in the Reserves or National Guard. ${ }^{4}$ A total of 902 active duty servicemen comprise our analysis sample because they provide information on deployment assignment and the outcomes under study. Among this sample, 37.4 percent $(\mathrm{N}=337)$ report service exclusively in the United States (Non-Deployed), 16.5 percent $(\mathrm{N}=149)$ report overseas deployment in a non-combat zone (Non-Combat), and 46.1 percent $(\mathrm{N}$ $=416)$ report deployment in a combat zone (Combat). Of those deployed in a combat zone, 25.6 percent $(\mathrm{N}=231)$ report deployment without enemy firefight (Combat Non-Fire), and 20.5 percent $(\mathrm{N}=185)$ report deployment with enemy firefight (Combat Fire). Among all those deployed to a combat zone, 93.5 percent $(\mathrm{N}=389)$ reported combat service in the post-9/11

\footnotetext{
${ }^{3}$ In Add Health Wave IV, 1,112 of the respondent reported military service. Of those, two individuals responded that they do not know whether they served in the active duty.

${ }^{4}$ The weighted means for military service in the 2008 Add Health are comparable to weighted means in the 2008 Current Population Survey and the 2008 American Community Survey. For instance, in the 2008 ACS, 5.0 percent reported active duty service, as compared to 5.87 percent in Add Health. The unweighted means are slightly larger in the Add Health due to an oversample of racial minorities, who are more likely to serve in the military.
} 
period; among those deployed to a combat zone with enemy firefight, 95.7 percent $(\mathrm{N}=177)$ of service was in the post-9/11 period..$^{5}$

Our dependent variable of interest, Migraine, is a post-deployment medical diagnosis of migraine headache. Respondents are asked:

Has a doctor, nurse, or other health care provider ever told you that you have or had migraine headaches?

How old were you when a doctor, nurse, or other health care provider diagnosed you with migraine headaches?

We used responses to each of the questionnaire items above, as well as information on the respondent's age and reported timing of military service, to construct a dichotomous measure of Migraine equal to 1 if the respondent had been diagnosed with migraine headache following their service start date. Among the sample of active-duty deployed respondents, 8.1 percent $(\mathrm{N}=$ 73) report a medical diagnosis of migraine headache after enlistment.

Our measure of Migraine has a number of strengths and weaknesses. A strength of the measure is that it is a medical, rather than self-diagnosis, which may be important inasmuch medical professionals are better able to identify migraine headache and distinguish it from other types of headache. On the other hand, a medical diagnosis measure could capture access to and use of medical services. To mitigate these concerns, our analysis will compare active-duty deployed soldiers who are likely to have similar access to health care services, and will also control for health insurance status in all models as well as frequency of routine medical checkups.

\footnotetext{
${ }^{5}$ We identified those who served in the post-9/11 period as those whose first military service started after September 2001.
} 
The timing of our migraine measure is not ideal in that it would be preferable to have a measure of post-deployment rather than post-enlistment migraine headache. While our data contain information on length of combat deployment and enlistment date so that a window of deployment timing can be inferred under some circumstances, specific dates are not provided. However, there are reasons to imagine that measurement error is likely to be small. Among those who enlisted and were deployed in the post-9/11 period, the vast majority were deployed within two years of enlistment. Moreover, sensitivity analysis using measures of migraine diagnosis that occurred 2 to 3 years after enlistment produced qualitatively similar results to those presented below. Finally, estimates of the effect of combat on Migraine may be considered a lower-bound estimate because our measure of migraine headache will not permit us to capture whether combat exposure exacerbated migraine attacks among those with pre-existing medical diagnosis of migraine headache. Unfortunately, there is no information on severity or frequency of attacks reported in the Add Health.

Another advantage of the Add Health data set is that it also provides information on several triggers of migraine headache that combat exposure may affect: sleep disruption, psychological stress, and physical injuries (including head injuries). With regard to sleep disruption, we generate two measures based on respondents' answers to the following questionnaire items:

Over the past four weeks, how often did you have trouble staying asleep throughout the night? For example, you woke up several times a night or woke up earlier than you planned to? (Possible answers: never, less than once a week, 1 or 2 times a week, 3 or 4 times a week, 5 or more times a week) 
Over the past four weeks, how often did you have trouble falling asleep? (Possible answers: never, less than once a week, 1 or 2 times a week, 3 or 4 times a week, 5 or more times a week)

The variable Stay Asleep is set equal to 1 if the respondent had trouble staying asleep one or two times or more per week in the past four weeks and is set equal to 0 otherwise. The variable Fall Asleep is set equal to 1 if the respondent had trouble falling asleep one or two times or more per week in the past four weeks and is set equal to 0 otherwise. In our sample, 23.2 percent of active duty deployed servicemen reported difficulty staying asleep and 17.4 percent reported difficulty falling asleep.

With regard to stress, we employ three measures of stress. First, we use the Cohen stress scale. This measure is constructed by Add Health based on responses to the following questionnaire items:

In the last 30 days, how often have you felt that you were unable to control the important things in your life? (Possible answers: never $(=0)$, almost never $(=1)$, sometimes $(=2)$ fairly often $(=3)$, very often $(=4)$ )

In the last 30 days, how often have you felt confident in your ability to handle your personal problems? (Possible answers: never $(=0)$, almost never $(=1)$, sometimes $(=2)$ fairly often (=3), very often $(=4)$ )

In the last 30 days, how often have you felt that things were going your way? (Possible answers: never $(=0)$, almost never $(=1)$, sometimes $(=2)$ fairly often $(=3)$, very often $(=4))$

In the last 30 days, how often have you felt that difficulties were piling up so high that you could not overcome them? (Possible answers: never $(=0)$, almost never $(=1)$, sometimes (=2) fairly often (=3), very often (=4))

The second and third items above were reverse coded and the numerical response to each question summed to form the Cohen stress scale, which ranges from 0 (low-stress) to 16 (high stress). 
Our second measures of stress is a dichotomous measure indicating whether the respondent had received a medical diagnosis of post-traumatic stress disorder (PTSD) using responses to the following questionnaire item:

Has a doctor, nurse or other health care provider ever told you that you have or had post-traumatic stress disorder?

Following Cesur et al. (2011), respondents who answered "yes" were coded as 1 and those who answered "no" as 0 .

Our final measure of stress is a measure of a violent combat event, which is likely to be correlated with high stress for soldiers: killing someone in action. The Add Health asks:

Did you ever kill or think you killed someone?

We generate a dichotomous variable, Killed, equal to one is a respondents answered in the affirmative and zero otherwise.

In addition to sleep disorders and stress, we also measure a physical channel through which combat exposure might affect migraine headache: physical injury, which might include head injury, though we cannot specifically measure injury type in these data. Respondents in the Add Health were asked:

During your combat deployment, were you wounded or injured?

A dichotomous variable, Injured, is set equal to one if the respondent reported in the affirmative and zero otherwise. 
Table 1 presents the means of Migraine, Stay Asleep, Fall Asleep, Cohen, PTSD, Killed, and Injured by deployment assignment of the respondent. Cross-tabulations indicate that those deployed to combat zones with enemy firefight have significantly higher rates of migraine headache, sleeping problems, and stress relative to their counterparts deployed to combat zones without enemy firefight or to non-combat zones. Among those deployed to combat zones with enemy firefight, 11.9 percent report migraine headache as compared to 5.6 percent of those deployed to combat without enemy firefight and 6.0 percent of those deployed overseas to noncombat zones. Along the same lines, 21.3 percent of those deployed to combat zones report difficulty falling asleep at least two times per week in the last four weeks as compared to 16.1 percent of those who were assigned to overseas non-combat zones or combat zones without enemy firefight. However, at baseline (prior to deployment), we find no significant differences between migraine headache, any other headache, or sleep problems between those who are later assigned to combat zones with firefight versus any other overseas deployment. This is at least suggestive evidence that deployment assignment is unrelated to pre-existing health conditions.

\section{Identification}

Analyses of the causal effects of military service on health have often relied on the draft lottery to generate exogenous variation in service (Angrist et al., 2010; Hearst et al., 1986; Bedard and Deschenes, 2004; Dobkin and Shabani, 2009). The absence of a draft in the Global War on Terrorism has led researchers to seek new sources of identifying variation (and different local average treatment effects).

The most common identification strategy used in the medical literature (see, for example, Wells et al., 2010; Smith et al., 2009; Jacobson et al., 2008) has been to compare those deployed 
to combat with non-deployed active duty and reservist soldiers. However, non-deployment may not be exogenous, as selection into the Reserves or National Guard - which comprise a relatively larger share of non-deployed armed services personnel than active duty soldiers - may be nonrandom (Hirsch and Mahey, 2003) and active-duty soldiers who remain non-deployed for long periods of time may be non-deployable for reasons related to physical or mental health (Department of the Army AR 614-30, 2010; Cesur et al., 2011).

We rely on evidence that the location of overseas deployment assignment among active duty deployers is unrelated to individual or family-level characteristics or to prior health to identify the effect of combat exposure on migraine headache and migraine-related triggers. In citing the seminal work by Lyle (2006) and Engel et al. (2010) on this identification approach, Resul et al., (2011; p. 5) argue that individual soldiers have little discretion over the nature of their deployment assignments. It is the circumstances of military operation along with the readiness and availability of the individual units that determine the timing and the location of each deployment (Engel et al., 2010):

"[T]he timing of the move and assignment of a soldier to a subordinate army unit are largely independent of a soldier's preferences... [T] he 'needs of the army' also determine the missions that a soldier's company receives." (Lyle, 2006, p. 323)'”

In short, the deployment assignment of individual soldiers is independent of their characteristics such as perceived courage or bravery, mental condition, or family background, but the needs of the military.

Moreover, when Human Resources Command makes deployment decisions, it has only a small set of military-specific and demographic characteristics of units (Engel et al., 2010). 
Thus, it is incumbent upon us to show some descriptive evidence that - conditional on military rank, timing of service in the military, branch of service, and occupation (four-digit Standard Occupational Classification code) ${ }^{6}$ - deployment assignment is unrelated to a wide set of individual, family background characteristics, including: age, race, ethnicity, gender, measured height, measured weight, years of schooling attained, earnings, physical health, marital status, religiosity, maternal educational attainment, parental marital status and income when the respondent was an adolescent, an abridged version of the Peabody Picture and Vocabulary Test (PPVT), health insurance status, medical checkup in the last year, as well as pre-deployment migraine status, sleep disorders, and stress. ${ }^{7}$

We attempt such a descriptive strategy in Table 2. In column (1), we restrict the sample to those who were deployed overseas and regress an indicator for whether the assignment was to a combat zone (with or without firefight) on the full set of observables discussed above. We find that assignment to a combat zone is unrelated to the wide set of individual and family background characteristics or prior health. ${ }^{8}$ Joint significance tests reflect a similar pattern of results.

In column (2), we restrict the sample to only those respondents who were assigned to combat zones and regress an indicator for whether the respondent was assigned to a location with enemy firefight on the set of observables; and in column (3), we restrict the sample to those assigned to combat zones with firefight or those assigned to non-combat zones overseas and

\footnotetext{
${ }^{6}$ Military-specific occupations were measured with respect to the respondent's job last year at Wave IV. The categories include Military Officer Special and Tactical Operations Leaders/Managers, Infantry Officers, Special Forces, Armored Assault Vehicle Officers, Artillery and Missile Officers, Air Crew Officers, Command and Control Center Officers, and First-Line Enlisted Military Supervisors/Managers, and Radar and Sonar Technicians. Occupations in engineering and medicine are measured in similar detail.

${ }^{7}$ The means of each of these variables, by deployment assignment are reported in Appendix Table 1.

${ }^{8}$ Only "other race" (relative to whites) is marginally significant at the 10 percent level.
} 
regress an indicator for whether the respondent was assigned to a combat zone with enemy firefight on the set of observables. In each case, the empirical evidence points to very little support for the hypothesis that deployment assignment is related to family and individual background characteristics, including prior health. We view this evidence as at least suggestive that deployment assignment is exogenous to health. ${ }^{9}$

For our main identification approach, we pool active-duty personnel (excluding those who served exclusively in the Reserves or National Guard) and estimate the following equation:

Migraine $_{i s}=\alpha+\delta_{1}$ Combat Fire $_{i s}+\delta_{2}$ Non-Combat $_{i s}+\delta_{3}$ Non-Deployed $_{i s}+\mathrm{X}_{\mathrm{is}} \beta+v_{\mathrm{s}}+\varepsilon_{\mathrm{is}},(1)$

where $i$ denotes active-duty respondent $i$, s denotes the middle or high school that the respondent attended at Wave $\mathrm{I}, \mathrm{X}_{\mathrm{is}}$ is a vector containing each of the observable individual demographic, family background, and military characteristics, described above and $v_{s}$ is a set of school fixed effects to capture any unobserved community characteristics of the soldier that could be related to branch or occupation selection. Note that the omitted category in equation (1) is assignment to combat zone without firefight. In alternate specifications, we also include controls for predeployment migraine status, a neuroticism scale, and health, which should not affect our estimates of the effect of combat exposure if deployment assignment is exogenous.

Under the assumption that, conditional on occupation, rank and branch, overseas deployment assignment is exogenous, $\delta_{1}-\delta_{2}$ can be interpreted as the effect of deployment to a combat zone with firefight relative to a non-combat zone, while $\delta_{1}$ can be interpreted as the marginal effect of deployment to a combat zone with firefight relative to a combat zone without

\footnotetext{
${ }^{9}$ A similar pattern of results is observed when we restrict the sample to only those who were serving in the Army. These findings are shown in Appendix Table 2.
} 
firefight. If assignment to a non-combat zone is associated with fewer migraine triggers than assignment to a combat zone without firefight - perhaps due to less stress, fewer environmental changes - it is possible that $\left|\delta_{1}-\delta_{2}\right|>\left|\delta_{1}\right|$. On the other hand, if migraine effects are driven primarily by the physical health effects of war, such as injuries sustained while engaging the enemy in firefight, or via combat-related stresses, then the estimates of $\delta_{1}-\delta_{2}$ and $\delta_{1}$ might be similar in magnitude.

\section{Estimates of the Effect of Combat Exposure on Migraine Headache}

Our main results appear in Tables 3-7. Because the Add Health data are school-based, standard errors are clustered on the school. Our focus is on estimates of $\delta_{1}$ and $\delta_{1}-\delta_{2}$. Coefficient estimates on the control variables are omitted for brevity, but are available in Appendix Table $3 .^{10}$

As shown in Table 3, assignment to a combat zone with firefight relative to a combat zone without firefight is associated with a 10.4 percentage- point increase in migraine headache. This is similar in magnitude to the effect of getting assigned to a combat zone with firefight relative to a non-combat zone, which is estimated as $11.1(10.4-(-0.07))$ percentage-points. This finding is consistent with the hypothesis that assignment to a combat zone alone is not necessarily the source of migraine headache, but rather the physical and psychological scars sustained while engaged in firefight are what lead to this condition. In columns (2) to (7), we present the estimates from equation (1) by branch of service. We find that the effect obtained in column (1) is driven by those who served in the Army and is largest for those who served in the Army during the post-9/11 period. As shown in columns (2) and (7), the coefficient estimates

\footnotetext{
${ }^{10}$ The findings in Appendix Table 4 support the hypothesis that deployment assignment is exogenous to the observable controls. This table shows that the magnitude of the estimated association between combat exposure and migraine headache is generally unaffected by the inclusion of these controls.
} 
are still significant at the 10 percent level despite a reduction in the sample size by about twothirds.

In Table 4, we further assess the sensitivity of the estimates from equation (1) to additional relevant controls. In Panel A, we present estimates with lagged migraine status measured in Wave I, assessed not by medical diagnosis, but by a parental report that the respondent suffered from migraine headache in adolescence. This variable would account for the possibility that some individuals may be more prone to environmental triggers of migraine due to genetic factors or certain early life experiences. Controlling for lagged migraine headache causes no appreciable change in the estimates reported in Table 4. This finding lends further support to our identifying assumption that deployment assignment is independent of differences across individuals in their pre-deployment characteristics, including prior migraine headache.

A number of studies have shown a link between migraine headache and neuroticism (Brandt et al., 1990; Merikangas et al., 1993; Breslau and Andreski, 1995; Kentle, 1997; Cao et al., 2002). If differences in personality across soldiers are somehow associated with their chances of deployment to a combat zone and engaging in firefight, then our assumption of the exogeneity of deployment assignment would be violated. To test the sensitivity of our results to personality, we constructed a neuroticism personality scale using a number of questions in Add Health (Sabia and Rees, 2011). Specifically, respondents are asked whether they "strongly agree" (1), "agree" (2), "neither agree nor disagree" (3), "disagree" (4), or "strongly disagree" (5), with the each of the following statements:

(i) I have frequent mood swings;

(ii) I am relaxed most of the time;

(iii) I get upset easily; and

(iv) I seldom feel blue. 
Items (i) and (iii) are reverse coded and the neuroticism scale is calculated by summing the responses to each questionnaire item. This scale, which ranges in values from 4 to 20 , is increasing in symptoms of neuroticism. As shown in Panel B of Table 4, our main results are robust to controlling for personality (though the coefficients are less precisely estimated for the post-9/11 sample).

Thus far, our results indicate that engaging in firefight in a combat zone is associated with an increased risk of migraine headache. Next, we examine whether a higher frequency of enemy firefight affects the likelihood of migraine headache. To test this question, we estimate a regression of migraine headache on the frequency of firefight among the sub-sample who served in a combat zone. As shown in column (1) of Table 5, our results suggest that the largest migraine effects are observed for those who reported 20 or more enemy firefight experiences in combat zones. Specifically, those who engaged in an enemy firefight at least 20 times are 11 percentage points more likely to suffer migraine headaches than those who did not engage in firefight.

In column (2), we examine whether longer combat deployment lengths are associated with an increased risk of migraine headache. We find little evidence that longer deployment lengths are correlated with migraine headache. Finally, in column (3), we include both combat deployment length and frequency of enemy firefight on the right hand-side of the estimating equation and find that, conditional on deployment length, more frequent enemy firefight remains positively associated with the probability of migraine headache. Consistent with the finding in column (1), we find that those who engaged in 20 or more enemy fight continue to suffer migraine headache by an 11 percentage-points higher likelihood than those who did not experience any firefight. 
Taken together, the findings in Tables 2-5 provide strong evidence that combat exposure is positively related to migraine headache. We next turn to estimates of the effect of combat exposure on several triggers of migraine headache and examine how effects on these triggers mediate the relationship between combat exposure and migraine headache.

\section{Estimates of Effect of Combat Exposure on Potential Migraine Triggers}

In Table 6, we explore the extent to which a number of potential triggers for migraine headaches_-including sleep disorders, stress, PTSD, and physical injuries_-are affected by combat exposure. In Panels A and B, we regress our two measures of sleep disorders, trouble falling asleep and trouble staying asleep, on deployment assignment. As shown in Panel A, assignment to a combat zone with firefight relative to a non-combat zone is associated with substantial increases in the probability of having trouble falling asleep, particularly among those who served in the Army in the post-9/11 period. We find even stronger support for a positive association between combat missions and sleep disorders in Panel B. For example, those who served in a combat zone are 31.6 percentage points more likely to suffer migraine headache than those who served in a non-combat zone. The estimate from the post-9/11 sample is similarly large though it is less precisely estimated due to reduced sample size.

In Panel $\mathrm{C}$ of Table 6, we consider the association between combat zone experience and perceived stress measured by the Cohen Stress Scale. We find that assignment to a combat zone with firefight relative to non-combat service is generally associated with increased stress. In Panel D, we find evidence that combat zone experience with firefight is strongly associated with PTSD and this association is strongest among those in the Army deployed in the post 9/11 period. And, finally, in the last two panels of Table 6 (Panels E and F), we find that combat 
exposure is associated with increased likelihood of suffering physical injury and killing or believing to have killed someone in the battlefield.

Taken together, the results presented in Table 6 provide considerable evidence to suggest that combat exposure is associated with an increased risk of sleep disorders, psychological stress, and physical injuries, each of which have been identified in the medical literature as potential triggers for migraine headache. In Table 7, we descriptively examine the extent to which the inclusion of the triggers on the right hand side of our original estimating equation (equation 1) mediates the relationship between combat exposure and migraine headache.

In Panel of Table 7, we present results for the active duty sample and in Panel B for the Army sample. A comparison of the findings in column (1) with column (7) suggest that the inclusion of controls for sleep disorders, perceived stress, PTSD, and physical injury reduces the magnitude of the estimated relationship between combat exposure and migraine headache by 47 to 60 percent. Sleep disorders and the Cohen perceived stress score are relatively unimportant mediators, while PTSD, physical injury, and causing a death on the battlefield are relatively more important. We conclude that stress-related battlefield trauma and physical injury are the most plausible explanations for the positive relationship between combat exposure and migraine headache.

\section{Conclusions}

The growth of migraine headache among combat soldiers during the Global War on Terrorism has drawn the attention of military health professionals because of the short- and longterm health and productivity effects. However, there is little empirical evidence establishing a causal link between combat exposure and migraine headache. 
In this paper, we exploit the plausibly exogenous variation in deployment assignments of soldiers across and within combat zones to provide insights into this question. Using data from the National Longitudinal Study of Adolescent Health, we find that deployment to combat zones with enemy firefight is positively associated with migraine headache compared to deployment to combat zones without firefight or non-combat zones outside the United States. We also show that these effects are usually largest among those served in the Army in the post 9/11 period and those who engaged in frequent firefight with the enemy. These results are robust to controlling for pre-deployment migraine headache and differences in a large set of observable characteristics of the individuals including their personality.

In addition to these findings, the Add Health data allow us to explore some of the potential mechanisms through which the combat zone-migraine headache relationship operates, such as combat-induced sleep disorders, perceived stress, PTSD, physical injury, and killing an enemy soldier during a firefight. We find that while combat exposure increases the risk of experiencing all of these potential triggers, PTSD and physical injury are two main channels through which the relationship between combat and migraine headache operates.

Given the link between migraine headache and poor labor market outcomes, our findings imply that ex-military service personnel may be at substantial risk as they transition back to civilian life. The relevance of these findings is further heightened by the withdrawal of all U.S. troops from Iraq in December 2011and the recently announced plans for drawdown of forces from Afghanistan in the near future. A recent report by the Bureau of Labor Statistics highlights the difficulties faced by veterans in the labor market. For example, the unemployment rate for veterans who served in the military at any time since September 2001 averaged 11.5 percent 2010 compared with 9.4 percent unemployment experienced among non-veterans (Bureau of 
Labor Statistics, 2011). Veterans are more likely to be employed in industries such as mining, construction, manufacturing, transportation and utilities, which have experienced significant drops in employment during the most recent recession (Bureau of Labor Statistics, 2009). Our findings suggest that health problems such as migraine headaches may exacerbate the difficulties that veterans face finding productive jobs and will pose challenges to post-separation evaluation and training programs aiding former soldiers as they transition to civilian life.

A new set of pharmaceutical drugs called triptans are now in wide use, as are a number of over-the-counter migraine drugs (Rees and Sabia, 2011). These medications could potentially ameliorate some of the longer-run adverse socioeconomic consequences of migraine headache. However, many triptans have side effects that may be at least as severe as the symptoms they are intended to treat, including sleepiness, nausea, and dizziness (Gallagher and Kunkel 2003). Future research examining the longer-run migraine effects of combat exposure would benefit by the inclusion of information on migraine treatments. 


\section{References}

Angrist, Josh and John Johnson. 2000. "Effects of Work-Related Absences on Families: Evidence from the Gulf War," Industrial and Labor Relations Review 54(1): 41-58.

Angrist, Joshua D., Stacey H. Chen, and Brigham R. Frandsen. 2010. "Did Vietnam Veterans get Sicker in the 1990s? The Complicated Effects of Military Service on SelfReported Health." Forthcoming in the Journal of Public Economics.

Autor, David, Mark G. Duggan, and David S. Lyle. 2011. "Battle Scars? The Puzzling Decline in Employment and Rise in Disability Receipt among Vietnam Era Veterans," Forthcoming in the American Economic Review Papers and Proceedings.

Bedard, Kelley and Olivier Deschenes. 2004. "The Long-Term Impact of Military Service on Health: Evidence from World War II and the Korean War," American Economic Review 96(1): 176-194.

Brandt, J., D. Celentano, W. Stewart, M. Linet, and M.F. Folstein. 1990. "Personality and Emotional Disorder in a Community Sample of Migraine Headache Sufferers." American Journal of Psychiatry, Vol. 147, No 3, pp. 303-308.

Breslau, Naomi and Patricia Andreski. 1995. "Migraine, Personality, and Psychiatric Comorbidity." Headache, Vol. 35, No. 7, pp. 382-386.

Brody, David L., Christine L. Mac Donald, Ann M. Johnson, Dana Cooper, B.S., Elliot C. Nelson, Nicole J. Werner, Joshua S. Shimony, Abraham Z. Snyder, Marcus E. Raichle, John R. Witherow, Raymond Fang, Stephen F. Flaherty. 2011. "Detection of Blast-Related Traumatic Brain Injury in U.S. Military Personnel." The New England Journal of Medicine, June 2, 364: 2091-2100

Bureau of Labor Statistics. 2009. Employment Situation of Veterans: 2009. April 10, 2010.

Bureau of Labor Statistics. 2011. Employment Situation of Veterans: 2010. March 11, 2011.

Cao, Ming, Shiyang Zhang, Keyong Wang, Yehan Wang, and Wei Wang. 2002. "Personality Traits in Migraine and Tension-Type Headaches: A Five-Factor Model Study." Psychopathology, Vol. 35, No.4, pp.:254-258.

Cesur, Resul, Joseph J. Sabia, and Erdal Tekin. 2011. "The Psychological Costs of War: Military Combat and Mental Health," National Bureau of Economic Research Working Paper 16927.

Chasman Daniel I, Markus Schürks, Verneri Anttila, Boukje de Vries, Ulf Schminke, Lenore J Launer, Gisela M Terwindt, Arn M J M van den Maagdenberg, Konstanze Fendrich, Henry Völzke, Florian Ernst, Lyn R Griffiths, Julie E Buring, Mikko Kallela, Tobias Freilinger, Christian Kubisch, Paul M Ridker, Aarno Palotie, Michel D Ferrari, Wolfgang Hoffmann, 
Robert Y L Zee \& Tobias Kurth. "Genome -wide association study reveals three susceptibility loci for common migraine in the general population." Nature Genetics, Published online 12 June 2011.

Department of the Army. 2010. Army Regulation 614-30. Available at: http://www.apd.army.mil/pdffiles/r614_30.pdf; Retrieved June 12, 2011.

Dobkin, Carlos and Reza Shabani. 2009. "The Health Effects of Military Service: Evidence from the Vietnam Draft," Economic Inquiry 47(1): 69-80.

Engel, Rozlyn C., Luke B. Gallagher, and David S. Lyle. 2010. "Military Deployments and Children's Academic Achievement: Evidence from Department of Defense Education Activity Schools," Economics of Education Review 29(1): 73-82.

De Fusco, M., Marconi, R., Silvestri, L., Atorino, L., Rampoldi, L., Morgante, L., Ballabio, A., Aridon, P., \& Casari, G. 2003. "Haploinsufficiency of ATP1A2 encoding the Na+/K+ pump $\alpha^{2}$ subunit associated with familial hemiplegic migraine Type 2," Nature Genetics, 333 (2), 192196.

de Vries, B., Freilinger, T., Vanmolkot, K.R., Koenderink J. B., Stam, A.H., Terwindt, G.M., Babini, E., van den Boogerd, E.H., van den Heuvel, J.J., Frants, R.R., Haan, J., Pusch, M., van den Maagdenberg, A.M., Ferrari, M.D., \& Dichgans, M. 2007. "Systematic analysis of three FHM genes in 39 sporadic patients with hemiplegic migraine," Neurology, 69 (23), 2170-2176.

Gade, Daniel M and Jeffrey B Wenger. 2011. 'Combat Exposure and mental Health: The LongTerm Effects Among US Vietnam and Gulf War Veterans," Health Economics 20: 401-416.

Goldberg, Lawrence D. 2005. "The Cost of Migraine and Its Treatment.” American Journal of Managed Care 11: S62-s67.

Harris, Kathleen Mullan, Carolyn Tucker Halpern, Pamela Entzel, Joyce Tabor, Peter S. Bearman, and J. Richard Udry. 2008. The National Longitudinal Study of Adolescent Health: Research Design.

Hazard, E., Munakata, J., Bigal, M. E., Rupnow, M. F. T. and Lipton, R. B. (2009), The Burden of Migraine in the United States: Current and Emerging Perspectives on Disease Management and Economic Analysis. Value in Health, 12: 55-64.

Hearst, N., T.B. Newman, and S.B. Hulley. 1986. "Delayed Effects of the Military Draft on Mortality: A Randomized Natural Experiment," New England Journal of Medicine 314(10): 620624.

Hirsch, Barry T., and Stephen L. Mehay. 2003. "Evaluating the Labor Market Performance of Veterans Using a Matched Comparison Group Design." Journal of Human Resources 38(3):673700 . 
$\mathrm{Hu}$ XH, Markson LE, Lipton RB, Stewart WF, Berger ML. 1999. "Burden of migraine in the United States: disability and economic costs,” Arch Intern Med. 159(8):813-818.

Jacobson, Isabel G., Margaret A.K. Ryan, Tomoko I. Hooper, Tyler C. Smith, Paul J. Amoroso, Edward J. Boyko, Gary D. Gackstetter, Timothy S. Wells, and Nicole S. Bell. 2008. "Alcohol Use and Alcohol-Related Problems Before and After Military Combat Deployment," Journal of the American Medical Association 300(6): 663-675.

Jankosky, C.J., T.I. Hooper, N.S. Granado, A. Scher, G.D. Gacksetter, E.J. Byko, T.C. Smith. 2011. "Headache Disorders in the Millennium Cohort:

Kaniecki, Robert G. 2002. "Migraine and Tension-Type Headache: An Assessment of Challenges in Diagnosis," Neurology 58(9): S15-S20.

Kentle, Robert L. 1997. "Elements of Neuroticism in Relation to Headache Symptomatology." Psychological Reports, Vol. 80. No. 1, pp. 227-235.

Lafrenière, Ronald G., M Zameel Cader, Jean-François Poulin, Isabelle Andres-Enguix, Maryse Simoneau, Namrata Gupta, Karine Boisvert, François Lafrenière, Shannon McLaughlan, Marie-Pierre Dubé, Martin M Marcinkiewicz, Sreeram Ramagopalan, Olaf Ansorge, Bernard Brais, Jorge Sequeiros, Jose Maria Pereira-Monteiro, Lyn R Griffiths, Stephen J Tucker, George Ebers, and Guy A Rouleau. 2010. "A dominant-negative mutation in the TRESK potassium channel is linked to familial migraine with aura." Nature Medicine 16: 1157-1160.

Lew, Henry L., Pei-Hsin Lin, Jong-Ling Fuh, Shuu-Jiun Wang, David J. Clark, and William C. Walker. 2006. "Characteristics and treatment of Headache After Traumatic Brain Injury: A Focused review," American Journal of Physical Medicine and Rehabilitation 85(7): 619-627.

Lipton, R.B., Bigal, M.E., Diamond M., Freitag, F., Reed, M.L., \& Stewart, W.F. 2007. "Migraine prevalence, disease burden, and the need for preventive therapy," Neurology, 68 (5), 343-349.

Lipton, Richard B., Walter F. Stewart, Seymour Diamond, Merle L. Diamond, and Michael L. Reed. 2001. "Prevalence and Burden of Migraine in the United States: Data from the American Migraine Study II." Headache: The Journal of Head and Face Pain 41(7):646-57.

Lyle, David S. 2006. "Using Military Deployments and Job Assignments to Estimate the Effect of Parental Absences and Household Relocations on Children's Academic Achievement," Journal of Labor Economics 24(2): 319-350.

Lyngberg, A. C., B. K. Rasmussen, T. Jørgensen1, and R. Jensen. 2005. "Incidence of Primary Headache: A Danish Epidemiologic Follow-up Study." American_Journal of Epidemiology 161(11): 1066-73. 
Martin, Christopher B. 2008. "Migraine and Other Headaches, Active Components, U.S. Armed Forces, 2001-2007," Medical Surveillance Monthly Report 15(4): 6-15.

Mayo Clinic. 2011. "Migraine Headache: Symptoms, Causes, Risk Factors," Mayo Foundation for Medical Education and Research. Available at: http://www.mayoclinic.com/health/migraine-headache/DS00120; Retrieved June 13, 2011.

Merikangas, Kathleen R., Denise E. Stevens, and Jules Angst. 1993. "Headache and Personality: Results of a Community Sample of Young Adults." Journal of Psychiatric Research, Vol. 27, No. 2, pp. 187-196.

Osterhaus JT, Gutterman DL, Plachetka JR. 1992. "Healthcare resource and lost labour costs of migraine headache in the US." Pharmacoeconomics. 2(1):67-76.

Rees, Daniel I. and Joseph J. Sabia. 2010. "The Effect of Migraine Headache on Educational Attainment and Earnings," Working Paper, Presented at George Washington University Department of Economics.

Rees, Daniel I. and Joseph J. Sabia. 2011. "The Effect of Migraine Headache on Educational Attainment," The Journal of Human Resources 46(2): 317-332.

Russell, M.B., \& Olesen, J. 1995. "Increased familial risk and evidence of genetic factor in migraine," British Medical Journal 311 (7004), 541-544.

Sabia, Joseph J. and Daniel I. Rees. 2011. "Individual Heterogeneity and Reverse Causality in the Relationship between Migraine Headache and Educational Attainment," Economics of Education Review 30(5): 913-923.

Seifert, Tad D. and Randolph W. Evans. 2010. "Posttraumatic Headache: A Review," Current Pain and Headache Reports 14(4): 292-298.

Simpson, Grahame, Richard Mohr, and Anne Redman. 2000. "Cultural Variations in the Understanding of Traumatic Brain Injury and Brain Injury Rehabilitation," Brain Injury, 14(2): 125-140.

Smith, Tyler C., Margaret A.K. Ryan, Deborah L. Wingard, Donald J. Slymen, James F. Sallis, Donna Kritz-Silverstein. 2009. "New Onset and Persistent Symptoms of Post-Traumatic Stress Disorder Self Reported After Deployment and Combat Exposures: Prospective Population Based US Military Cohort Study," British Medical Journal 336(7640): 1-11.

Stewart, Walter F., Richard B. Lipton, David D. Celentano, and Michael L. Reed. 1992. "Prevalence of Migraine Headache in the United States. Relation to Age, Income, Race, and Other Sociodemographic Factors." The Journal of the American Medical Association 267(1):649. 
Theeler, Brett J., Jay C. Erickson. 2009. "Mild Head Trauma and Chronic Headaches in Returning U.S. Soldiers," Headache. 2009;49(4):529-534

Theeler, Brett J., Kimbra Kenney, Olga A. Prokhorenko, Ulgen S. Fideli, William Campbell, and Jay C. Erickson. 2010. "Headache Triggers in the U.S. Military," Headache: The Journal of Head and Face Pain 50(5): 790-794

Ulrich, V., Gervil, M., Kyvik, K.O., Olesen, J., \& Russell, M.B. 1999. "Evidence of a genetic factor in migraine with aura: a population-based Danish twin study," Annals of Neurology, 45 (2), 242-246.

Stewart WF, Ricci JA, Chee E, Morganstein D, Lipton R. 2003. "Lost productive time and cost due to common pain conditions in the US workforce." Journal of the American Medical Association, Vol. 290: 2443-2454.

Theeler, Brett J., Renee Mercer, and Jay C. Erickson. 2008. "Prevalence and Impact of Migraine among U.S. Army Soldiers Deployed in Support of Operation Iraqi Freedom," Headache: The Journal of Head and Face Pain 48(6): 876-882.

Theeler, Brett J. and Jay C. Mercer. 2009. "Mild Head Trauma and Chronic Headaches in Returning U.S. Soldiers," Headache: The Journal of Head and Face Pain 49(4): 529534.

Verneri, Anttila, Hreinn Stefansson, Mikko Kallela, Unda Todt, Gisela M Terwindt, M Stella Calafato, Dale R Nyholt, Antigone S Dimas, Tobias Freilinger, Bertram MüllerMyhsok, Ville Artto, Michael Inouye, Kirsi Alakurtti, Mari A Kaunisto, Eija Hämäläinen, Boukje de Vries, Anine H Stam, Claudia M Weller, Axel Heinze, Katja Heinze-Kuhn, Ingrid Goebel, Guntram Borck, Hartmut Göbel, Stacy Steinberg, Christiane Wolf, Asgeir Björnsson, Gretar Gudmundsson, Malene Kirchmann, Anne Hauge, Thomas Werge, Jean Schoenen, Johan G Eriksson, Knut Hagen, Lars Stovner, H-Erich Wichmann, Thomas Meitinger, Michael Alexander, Susanne Moebus, Stefan Schreiber, Yurii S Aulchenko, Monique M B Breteler, Andre G Uitterlinden, Albert Hofman, Cornelia M van Duijn, Päivi Tikka-Kleemola, Salli Vepsäläinen, Susanne Lucae, Federica Tozzi, Pierandrea Muglia, Jeffrey Barrett, Jaakko Kaprio, Markus Färkkilä, Leena Peltonen, Kari Stefansson, John-Anker Zwart, Michel D Ferrari, Jes Olesen, Mark Daly, Maija Wessman, Arn M J M van den Maagdenberg, Martin Dichgans Christian Kubisch, Emmanouil T Dermitzakis, Rune R Frants, and Aarno Palotie for the International Headache Genetics Consortium. 2010. "Genome-wide association study of migraine implicates a common susceptibility variant on 8q22.1," Nature Genetics 42, 869-873.

Vargas, Bert B. 2009. "Posttraumatic Headache in Combat Soldiers and Civilians: What Factors Influence the Expression of Tension-type Versus Migraine Headache," Current Pain and Headache Reports 13: 470-473. 
Wells, Timothy S., Cynthia A. LeardMann, Sarah O. Fortuna, Besa Smith, Tyler C. Smith, Margaret Ryan, Edward Boyko, and Dan Blazer. 2010. "A Prospective Study of Depression Following Combat Deployment in Support of the Wars in Iraq and Afghanistan," American Journal of Public Health 100(1): 90. 
Table 1: Descriptive Statistics of Outcome Variables by Military Service

\begin{tabular}{|c|c|c|c|c|c|c|c|}
\hline Variable & $\begin{array}{l}\text { Active } \\
\text { Duty } \\
\text { Sample }\end{array}$ & $\begin{array}{l}\text { Overseas } \\
\text { Sample }\end{array}$ & $\begin{array}{c}\text { Exclusively } \\
\text { U.S. } \\
\text { Sample }\end{array}$ & $\begin{array}{l}\text { Combat } \\
\text { Sample }\end{array}$ & $\begin{array}{c}\text { Overseas } \\
\text { Non-Combat } \\
\text { Sample }\end{array}$ & $\begin{array}{c}\text { Combat } \\
\text { Firefight } \\
\text { Sample }\end{array}$ & $\begin{array}{c}\text { Combat } \\
\text { No-Firefight } \\
\text { Sample } \\
\end{array}$ \\
\hline \multirow[t]{2}{*}{ Migraine } & 0.081 & 0.078 & 0.086 & 0.084 & 0.060 & 0.119 & 0.056 \\
\hline & $(0.273)$ & $(0.268)$ & $(0.281)$ & $(0.278)$ & $(0.239)$ & $(0.325)$ & $(0.231)$ \\
\hline \multirow[t]{2}{*}{ Cohen Perceived Stress Scale } & 4.393 & 4.316 & 4.522 & 4.441 & 3.966 & 4.584 & 4.326 \\
\hline & $(2.932)$ & $(3.013)$ & $(2.790)$ & $(2.992)$ & $(3.055)$ & $(3.046)$ & $(2.950)$ \\
\hline \multirow[t]{2}{*}{ Trouble Staying Asleep in The Past Four Weeks } & 0.232 & 0.233 & 0.230 & 0.249 & 0.188 & 0.295 & 0.213 \\
\hline & $(0.422)$ & $(0.423)$ & $(0.422)$ & $(0.433)$ & $(0.392)$ & $(0.457)$ & $(0.410)$ \\
\hline \multirow[t]{2}{*}{ Trouble Falling Asleep in The Past Four Weeks } & 0.174 & 0.178 & 0.167 & 0.184 & 0.161 & 0.213 & 0.161 \\
\hline & $(0.379)$ & $(0.383)$ & $(0.373)$ & $(0.388)$ & $(0.369)$ & $(0.411)$ & $(0.368)$ \\
\hline \multirow[t]{2}{*}{ Post Traumatic Stress Disorder (PTSD) } & 0.091 & 0.122 & 0.039 & 0.159 & 0.020 & 0.250 & 0.087 \\
\hline & $(0.288)$ & $(0.328)$ & $(0.193)$ & $(0.366)$ & $(0.141)$ & $(0.434)$ & $(0.282)$ \\
\hline \multirow[t]{2}{*}{ Injured } & 0.053 & 0.085 & 0.000 & 0.115 & 0.000 & 0.184 & 0.061 \\
\hline & $(0.225)$ & $(0.279)$ & 0.000 & $(0.320)$ & 0.000 & $(0.388)$ & $(0.239)$ \\
\hline \multirow[t]{2}{*}{ Killed or Believed Killed Someone } & 0.162 & 0.258 & 0.000 & 0.351 & 0.000 & 0.714 & 0.061 \\
\hline & $(0.369)$ & $(0.438)$ & 0.000 & $(0.478)$ & 0.000 & $(0.453)$ & $(0.239)$ \\
\hline \multirow[t]{2}{*}{ Wave 1 Migraine } & 0.090 & 0.101 & 0.073 & 0.105 & 0.089 & 0.099 & 0.110 \\
\hline & $(0.287)$ & $(0.302)$ & $(0.261)$ & $(0.307)$ & $(0.287)$ & $(0.300)$ & $(0.314)$ \\
\hline \multirow[t]{2}{*}{ Wave 1 Headache More Than Once a Week } & 0.046 & 0.039 & 0.056 & 0.043 & 0.027 & 0.049 & 0.039 \\
\hline & $(0.208)$ & $(0.194)$ & $(0.231)$ & $(0.204)$ & $(0.162)$ & $(0.216)$ & $(0.194)$ \\
\hline \multirow[t]{2}{*}{ Wave 1 Sleep Problems More Than Once a Week } & 0.220 & 0.188 & 0.273 & 0.190 & 0.181 & 0.205 & 0.178 \\
\hline & $(0.414)$ & $(0.391)$ & $(0.446)$ & $(0.393)$ & $(0.387)$ & $(0.405)$ & $(0.383)$ \\
\hline Observations & 902 & 565 & 337 & 416 & 149 & 185 & 231 \\
\hline
\end{tabular}

Standard deviations are in parentheses. Unweighted means are generated using Waves I and IV of the National Longitudinal Study of Adolescent Health 


\begin{tabular}{|c|c|c|c|}
\hline & $\begin{array}{c}\text { (1) } \\
\text { Combat } \\
\text { vs. } \\
\text { Non-Combat }\end{array}$ & $\begin{array}{c}(2) \\
\text { Combat } \\
\text { Firefight } \\
\text { vs. } \\
\text { Combat } \\
\text { Non-Firefight } \\
\end{array}$ & $\begin{array}{c}(3) \\
\text { Combat } \\
\text { Firefight } \\
\text { vs. } \\
\text { Non-Combat }\end{array}$ \\
\hline Wave 1: Health is Excellent & $\begin{array}{c}0.043 \\
(0.042)\end{array}$ & $\begin{array}{c}0.039 \\
(0.081)\end{array}$ & $\begin{array}{c}0.126 \\
(0.086)\end{array}$ \\
\hline Wave 1: Health is Poor & $\begin{array}{c}0.039 \\
(0.178)\end{array}$ & $\begin{array}{c}0.051 \\
(0.183)\end{array}$ & $\begin{array}{c}0.027 \\
(0.307)\end{array}$ \\
\hline Height in Inches & $\begin{array}{c}0.004 \\
(0.011)\end{array}$ & $\begin{array}{c}0.001 \\
(0.017)\end{array}$ & $\begin{array}{c}0.005 \\
(0.022)\end{array}$ \\
\hline Weight in Pounds & $\begin{array}{l}-0.000 \\
(0.001)\end{array}$ & $\begin{array}{l}-0.000 \\
(0.001)\end{array}$ & $\begin{array}{l}-0.000 \\
(0.002)\end{array}$ \\
\hline Religion: Protestant & $\begin{array}{c}0.048 \\
(0.099)\end{array}$ & $\begin{array}{c}0.042 \\
(0.119)\end{array}$ & $\begin{array}{c}0.085 \\
(0.120)\end{array}$ \\
\hline Religion: Catholic & $\begin{array}{c}0.021 \\
(0.123)\end{array}$ & $\begin{array}{c}-0.032 \\
(0.114)\end{array}$ & $\begin{array}{c}0.015 \\
(0.209)\end{array}$ \\
\hline Religion: Other Christian & $\begin{array}{c}0.030 \\
(0.090)\end{array}$ & $\begin{array}{c}-0.118 \\
(0.113)\end{array}$ & $\begin{array}{c}-0.003 \\
(0.115)\end{array}$ \\
\hline Religion: Other & $\begin{array}{l}-0.148 \\
(0.136)\end{array}$ & $\begin{array}{c}-0.186 \\
(0.159)\end{array}$ & $\begin{array}{l}-0.239 \\
(0.203)\end{array}$ \\
\hline Male & $\begin{array}{c}0.076 \\
(0.092)\end{array}$ & $\begin{array}{c}0.246 \\
(0.153)\end{array}$ & $\begin{array}{c}0.236 \\
(0.186)\end{array}$ \\
\hline Married & $\begin{array}{l}-0.045 \\
(0.079)\end{array}$ & $\begin{array}{c}0.007 \\
(0.087)\end{array}$ & $\begin{array}{l}-0.056 \\
(0.123)\end{array}$ \\
\hline Divorced & $\begin{array}{c}-0.074 \\
(0.074)\end{array}$ & $\begin{array}{l}-0.025 \\
(0.134)\end{array}$ & $\begin{array}{c}-0.064 \\
(0.144)\end{array}$ \\
\hline Age in Years & $\begin{array}{c}0.157 \\
(0.546)\end{array}$ & $\begin{array}{l}-0.657 \\
(0.822)\end{array}$ & $\begin{array}{c}0.741 \\
(1.024)\end{array}$ \\
\hline Age in Years Squared & $\begin{array}{l}-0.003 \\
(0.010)\end{array}$ & $\begin{array}{c}0.012 \\
(0.014)\end{array}$ & $\begin{array}{l}-0.013 \\
(0.018)\end{array}$ \\
\hline Race: Black & $\begin{array}{l}-0.028 \\
(0.080)\end{array}$ & $\begin{array}{c}-0.133 \\
(0.127)\end{array}$ & $\begin{array}{c}0.026 \\
(0.134)\end{array}$ \\
\hline Race: Other & $\begin{array}{l}0.161^{*} \\
(0.088)\end{array}$ & $\begin{array}{l}-0.114 \\
(0.154)\end{array}$ & $\begin{array}{c}0.234 \\
(0.183)\end{array}$ \\
\hline Race: Hispanic & $\begin{array}{l}-0.076 \\
(0.089)\end{array}$ & $\begin{array}{l}-0.089 \\
(0.139)\end{array}$ & $\begin{array}{l}-0.066 \\
(0.119)\end{array}$ \\
\hline Log of Personal Earnings & $\begin{array}{c}0.014 \\
(0.011)\end{array}$ & $\begin{array}{c}0.010 \\
(0.024)\end{array}$ & $\begin{array}{l}-0.003 \\
(0.016)\end{array}$ \\
\hline Education: College or More & $\begin{array}{c}0.015 \\
(0.080)\end{array}$ & $\begin{array}{l}-0.095 \\
(0.116)\end{array}$ & $\begin{array}{c}-0.139 \\
(0.150)\end{array}$ \\
\hline Picture Vocabulary Test Score & $\begin{array}{l}-0.001 \\
(0.002)\end{array}$ & $\begin{array}{l}-0.003 \\
(0.003)\end{array}$ & $\begin{array}{l}-0.004 \\
(0.005)\end{array}$ \\
\hline Log of Parental Income & $\begin{array}{c}0.050 \\
(0.065)\end{array}$ & $\begin{array}{c}0.038 \\
(0.088)\end{array}$ & $\begin{array}{c}0.122 \\
(0.088)\end{array}$ \\
\hline
\end{tabular}




\begin{tabular}{lccc} 
Parents are Married & -0.079 & -0.041 & -0.250 \\
& $(0.148)$ & $(0.202)$ & $(0.241)$ \\
Parents are Divorced, Separated or Widowed & -0.048 & -0.007 & -0.144 \\
& $(0.149)$ & $(0.196)$ & $(0.242)$ \\
Biological Mother's Education: Some College & -0.004 & -0.054 & -0.084 \\
& $(0.058)$ & $(0.094)$ & $(0.100)$ \\
Biological Mother's Education: College Degree or & -0.046 & 0.048 & -0.079 \\
More & & & \\
& $(0.070)$ & $(0.113)$ & $(0.119)$ \\
Had Check-up within Last Year & -0.025 & -0.012 & -0.100 \\
& $(0.062)$ & $(0.071)$ & $(0.114)$ \\
No Health Insurance & 0.001 & 0.148 & -0.065 \\
& $(0.087)$ & $(0.115)$ & $(0.128)$ \\
Wave I Depression & 0.100 & -0.054 & 0.114 \\
& $(0.080)$ & $(0.094)$ & $(0.125)$ \\
Wave I Migraine & 0.021 & 0.086 & -0.047 \\
& $(0.076)$ & $(0.140)$ & $(0.134)$ \\
Wave I Sleep Problems & 0.001 & 0.093 & 0.037 \\
& $(0.064)$ & $(0.101)$ & $(0.100)$ \\
Observations & & & 334 \\
R-squared & 565 & 416 & 0.580 \\
\hline
\end{tabular}

Robust standard errors corrected for clustering on the school are in parentheses. *, **, and $* * *$ indicate statistical significance at the $10 \%, 5 \%$, and $1 \%$ levels, respectively. All models control for school fixed effects and detailed occupation indicators. Models also include missing binary indicators for each of the control variables. 
Table 3: Estimated Effect of Deployment Assignment on Migraine Headache

\begin{tabular}{|c|c|c|c|c|c|c|c|}
\hline VARIABLES & $\begin{array}{c}\text { (1) } \\
\text { Active } \\
\text { Duty } \\
\text { Sample }\end{array}$ & $\begin{array}{c}(2) \\
\text { Army } \\
\text { Sample }\end{array}$ & $\begin{array}{c}\text { (3) } \\
\text { Non } \\
\text { Army } \\
\text { Sample } \\
\end{array}$ & $\begin{array}{c}(4) \\
\text { Navy } \\
\text { Sample }\end{array}$ & $\begin{array}{c}(5) \\
\text { Air } \\
\text { Force } \\
\text { Sample } \\
\end{array}$ & $\begin{array}{c}\text { (6) } \\
\text { Marine } \\
\text { Corps } \\
\text { Sample } \\
\end{array}$ & $\begin{array}{c}(7) \\
\text { Army } \\
9 / 11 \\
\text { Sample } \\
\end{array}$ \\
\hline Combat Zone with Firefight & $\begin{array}{c}0.104 * * * \\
(0.036)\end{array}$ & $\begin{array}{l}0.140^{*} \\
(0.072)\end{array}$ & $\begin{array}{c}0.076 \\
(0.051)\end{array}$ & $\begin{array}{l}-0.055 \\
(0.083)\end{array}$ & $\begin{array}{c}0.153 \\
(1.480)\end{array}$ & $\begin{array}{l}-0.006 \\
(0.144)\end{array}$ & $\begin{array}{l}0.156^{*} \\
(0.083)\end{array}$ \\
\hline Overseas Non-combat Service & $\begin{array}{c}-0.007 \\
(0.040)\end{array}$ & $\begin{array}{c}0.048 \\
(0.082)\end{array}$ & $\begin{array}{c}0.011 \\
(0.050)\end{array}$ & $\begin{array}{c}0.013 \\
(0.068)\end{array}$ & $\begin{array}{l}-0.113 \\
(1.416)\end{array}$ & $\begin{array}{l}-0.165 \\
(0.190)\end{array}$ & $\begin{array}{c}0.106 \\
(0.086)\end{array}$ \\
\hline Service Exclusively in the U.S. & $\begin{array}{c}0.028 \\
(0.028)\end{array}$ & $\begin{array}{c}0.052 \\
(0.072)\end{array}$ & $\begin{array}{c}0.045 \\
(0.047)\end{array}$ & $\begin{array}{c}0.043 \\
(0.082)\end{array}$ & $\begin{array}{c}-0.474 \\
(2.481)\end{array}$ & $\begin{array}{l}-0.196 \\
(0.221)\end{array}$ & $\begin{array}{c}0.051 \\
(0.091)\end{array}$ \\
\hline Observations & 902 & 359 & 543 & 234 & 152 & 156 & 306 \\
\hline R-squared & 0.279 & 0.508 & 0.390 & 0.827 & 0.990 & 0.861 & 0.565 \\
\hline$\delta_{\text {Combat ff }}-\delta_{\text {overseas nc }}=0 ?$ [p-value on F-test] & $0.111^{* *}[0.03]$ & $0.092[0.32]$ & $0.065[0.30]$ & $0.068[0.49]$ & $0.266[0.92]$ & $0.159[0.44]$ & $0.05[0.61]$ \\
\hline
\end{tabular}

Robust standard errors corrected for clustering on the school are in parentheses. *, **, and $* * *$ indicate statistical significance at the $10 \%, 5 \%$, and $1 \%$ levels, respectively. All models use the full set of controls shown in Appendix Table 1 along with school fixed effects and detailed occupation indicators. Models also include missing binary indicators for each of the control variables. 
Table 4: Estimated Effect of Deployment Assignment on Migraine Headache, Controlling Lagged Migraine Headache and Neuroticism

\begin{tabular}{|c|c|c|c|c|}
\hline VARIABLES & $\begin{array}{l}(1) \\
\text { Active } \\
\text { Duty } \\
\text { Sample }\end{array}$ & $\begin{array}{c}(2) \\
\text { Army } \\
\text { Sample }\end{array}$ & $\begin{array}{c}(3) \\
\text { Non } \\
\text { Army } \\
\text { Sample }\end{array}$ & $\begin{array}{c}(4) \\
\text { Army } \\
9 / 11 \\
\text { Sample }\end{array}$ \\
\hline \multicolumn{5}{|l|}{ Panel A: Lagged Migraine Controlled } \\
\hline Combat Zone with Firefight & $\begin{array}{c}0.108 * * * \\
(0.035)\end{array}$ & $\begin{array}{l}0.137 * \\
(0.072)\end{array}$ & $\begin{array}{c}0.070 \\
(0.046)\end{array}$ & $\begin{array}{l}0.149^{*} \\
(0.086)\end{array}$ \\
\hline Overseas Non-combat Service & $\begin{array}{l}-0.007 \\
(0.039)\end{array}$ & $\begin{array}{c}0.051 \\
(0.087)\end{array}$ & $\begin{array}{c}0.001 \\
(0.049)\end{array}$ & $\begin{array}{c}0.116 \\
(0.093)\end{array}$ \\
\hline Service Exclusively in the U.S. & $\begin{array}{c}0.033 \\
(0.027)\end{array}$ & $\begin{array}{c}0.054 \\
(0.069)\end{array}$ & $\begin{array}{c}0.044 \\
(0.047)\end{array}$ & $\begin{array}{c}0.062 \\
(0.094)\end{array}$ \\
\hline Lagged Migraine Indicator & $\begin{array}{l}0.093^{*} \\
(0.049)\end{array}$ & $\begin{array}{c}0.114 \\
(0.107)\end{array}$ & $\begin{array}{c}0.020 \\
(0.074)\end{array}$ & $\begin{array}{c}0.126 \\
(0.151)\end{array}$ \\
\hline $\begin{array}{l}\text { Observations } \\
\mathrm{R} \text {-squared } \\
\left.\delta_{\text {Combat ff }}-\delta_{\text {overseas nc }}=0 \text { ? [p-value on F-test }\right]\end{array}$ & $\begin{array}{c}902 \\
0.291 \\
0.115^{* *}[0.02] \\
\end{array}$ & $\begin{array}{c}359 \\
0.515 \\
0.086[0.35]\end{array}$ & $\begin{array}{c}543 \\
0.417 \\
0.069[0.24] \\
\end{array}$ & $\begin{array}{c}306 \\
0.571 \\
0.033[0.75] \\
\end{array}$ \\
\hline \multicolumn{5}{|c|}{ Panel B: Lagged Migraine and Current (Wave IV) Neuroticism Controlled } \\
\hline Combat Zone with Firefight & $\begin{array}{c}0.107 * * * \\
(0.035)\end{array}$ & $\begin{array}{l}0.135^{*} \\
(0.071)\end{array}$ & $\begin{array}{c}0.071 \\
(0.048)\end{array}$ & $\begin{array}{c}0.141 \\
(0.086)\end{array}$ \\
\hline Overseas Non-combat Service & $\begin{array}{l}-0.006 \\
(0.039)\end{array}$ & $\begin{array}{c}0.052 \\
(0.088)\end{array}$ & $\begin{array}{c}0.002 \\
(0.048)\end{array}$ & $\begin{array}{c}0.115 \\
(0.092)\end{array}$ \\
\hline Service Exclusively in the U.S. & $\begin{array}{c}0.032 \\
(0.027)\end{array}$ & $\begin{array}{c}0.055 \\
(0.069)\end{array}$ & $\begin{array}{c}0.045 \\
(0.047)\end{array}$ & $\begin{array}{c}0.063 \\
(0.092)\end{array}$ \\
\hline Lagged Migraine Indicator & $\begin{array}{l}0.093^{*} \\
(0.049)\end{array}$ & $\begin{array}{c}0.112 \\
(0.107)\end{array}$ & $\begin{array}{c}0.023 \\
(0.074)\end{array}$ & $\begin{array}{c}0.123 \\
(0.148)\end{array}$ \\
\hline Neuroticism Scale & $\begin{array}{c}0.005 \\
(0.004)\end{array}$ & $\begin{array}{c}0.005 \\
(0.011)\end{array}$ & $\begin{array}{c}0.005 \\
(0.005)\end{array}$ & $\begin{array}{c}0.008 \\
(0.014)\end{array}$ \\
\hline Observations & 902 & 359 & 543 & 306 \\
\hline R-squared & 0.293 & 0.516 & 0.419 & 0.574 \\
\hline$\delta_{\text {Combat ff }}-\delta_{\text {overseas nc }}=0 ?$ [p-value on F-test $]$ & $0.113^{* *}[0.03]$ & $0.080[0.37]$ & $0.069[0.24]$ & $0.026[0.80]$ \\
\hline
\end{tabular}


Table 5: Estimated Effect of Frequency of Enemy Firefight Engagement and Combat Deployment Length on Migraine Headache

\section{(1)}

0.074

$(0.082)$

0.036

(0.063)

$0.110^{*}$

(0.059)

Combat Zone Service Length: 120 to 180 Days

Combat Zone Service Length: >180 Days
(2)

0.074

$(0.083)$

0.039

$(0.068)$

$0.111^{*}$

$(0.063)$

$-0.021$

(0.074)

$-0.023$

0.004

$(0.077)$

(0.042)

Observations

416

416

416

R-squared

0.560

0.549

0.560

Robust standard errors corrected for clustering on the school are in parentheses. *,**, and *** indicate statistical significance at the $10 \%, 5 \%$, and $1 \%$ levels, respectively. All models use the full set of controls (except military service length) shown in Appendix Table 1 along with school fixed effects, detailed occupation indicators, lagged migraine, and current (Wave IV) neuroticism. Models also include missing binary indicators for each of the control variables. 
Table 6: Estimated Effect of Deployment Assignment on Migraine Triggers

\begin{tabular}{|c|c|c|c|c|}
\hline \multirow{4}{*}{ VARIABLES } & (1) & (2) & (3) & (4) \\
\hline & Active & Army & Non & Army \\
\hline & Duty & Sample & Army & $9 / 11$ \\
\hline & Sample & & Sample & Sample \\
\hline
\end{tabular}

\section{Panel A: Trouble Falling Asleep}

Combat Zone with Firefight

Overseas Non-combat Service

Service Exclusively in the U.S.

Observations

R-squared

$\delta_{\text {combat fire-fight }}-\delta_{\text {overseas nc }}=0 ?$ [p-value on F-test]

$\begin{array}{cccc}0.078 & 0.167 & 0.019 & 0.127 \\ (0.057) & (0.130) & (0.081) & (0.152) \\ 0.006 & -0.115 & 0.040 & -0.188 \\ (0.053) & (0.136) & (0.071) & (0.180) \\ -0.011 & -0.022 & 0.006 & -0.113 \\ (0.054) & (0.122) & (0.081) & (0.143)\end{array}$

$\begin{array}{cccc}892 & 350 & 542 & 298 \\ 0.284 & 0.549 & 0.430 & 0.593 \\ 0.072[0.13] & 0.282^{*}[0.07] & -0.021[0.80] & 0.315^{*}[0.08]\end{array}$

\section{Panel B: Trouble Staying Asleep}

Combat Zone with Firefight

Overseas Non-combat Service

Service Exclusively in the U.S.

$\begin{array}{cccc}0.147 * * & 0.294 * * & 0.124 & 0.310^{*} \\ (0.065) & (0.120) & (0.096) & (0.156) \\ -0.008 & -0.022 & 0.050 & 0.040 \\ (0.065) & (0.142) & (0.093) & (0.186) \\ -0.101 * & -0.102 & -0.044 & -0.132 \\ (0.059) & (0.125) & (0.079) & (0.162)\end{array}$

Observations

R-squared

$\delta_{\text {combat fire-fight }}-\delta_{\text {overseas nc }}=0$ ? [p-value on F-test]

$\begin{array}{cccc}892 & 350 & 542 & 298 \\ 0.291 & 0.577 & 0.449 & 0.605 \\ 0.155^{* *}[0.04] & 0.316^{* *}[0.04] & 0.074[0.41] & 0.270[0.16]\end{array}$

\section{Panel C: Cohen Stress Scale}

Combat Zone with Firefight

Overseas Non-combat Service

Service Exclusively in the U.S.

$\begin{array}{cccc}0.342 & 0.616 & 0.321 & 1.040 \\ (0.303) & (0.638) & (0.558) & (0.804) \\ -0.698^{* *} & -0.550 & -0.947 * * & -0.747 \\ (0.336) & (0.918) & (0.436) & (1.000) \\ -0.462 & -0.566 & -0.726 & -0.753 \\ (0.299) & (0.785) & (0.484) & (1.037)\end{array}$

Observations

R-squared

$\begin{array}{cccc}901 & 358 & 543 & 305 \\ 0.322 & 0.542 & 0.421 & 0.641\end{array}$

$\delta_{\text {combat fire-fight }}-\delta_{\text {overseas nc }}=0$ ? [p-value on F-test]

$1.040^{* * *}[0.00] \quad 1.166[0.17] \quad 1.268^{* *}[0.01] \quad 1.787^{* *}[0.03]$

\section{Panel D: PTSD}

Combat Zone with Firefight

Overseas Non-combat Service

Service Exclusively in the U.S.

Observations

R-squared

$\delta_{\text {i combat fire-fight }}-\delta_{\text {overseas nc }}=0 ?$ [p-value on F-test $]$

$\begin{array}{cccc}0.161 * * * & 0.200 * * & 0.106 * * & 0.176 \\ (0.038) & (0.091) & (0.047) & (0.111) \\ -0.072 * * * & -0.087 & -0.036 & -0.108 \\ (0.026) & (0.086) & (0.031) & (0.114) \\ -0.065 * & -0.085 & -0.023 & -0.082 \\ (0.033) & (0.107) & (0.034) & (0.137)\end{array}$

$\begin{array}{cccc}901 & 358 & 543 & 305 \\ 0.316 & 0.546 & 0.395 & 0.608 \\ 0.233^{* * *}[0.00] & 0.287^{* * *}[0.00] & 0.142^{* *}[0.01] & 0.284^{* *}[0.01]\end{array}$


Panel E: Injury (Combat Sample)

Combat Zone with Firefight

$0.113 * *$

0.327

$(0.283)$

0.040

0.296

(0.053)

188

$(0.057)$

(0.309)

Observations

416

0.474

0.689

228

180

R-squared

0.778

0.716

\section{Panel F: Killed or Believed Killed Someone}

Combat Zone with Firefight

$\begin{array}{cccc}0.647 * * * & 0.609 * * & 0.688 * * * & 0.559 * \\ (0.060) & (0.264) & (0.088) & (0.303)\end{array}$

Observations

416

188

228

180

R-squared

0.737

0.887

0.877

Robust standard errors corrected for clustering on the school are in parentheses. *,**, and *** indicate statistical significance at the $10 \%, 5 \%$, and $1 \%$ levels, respectively. All models use the full set of controls shown in Appendix Table 1 along with school fixed effects, detailed occupation indicators. In Panels A and B, lagged sleeping problems controlled. Lagged CES-D scale in Panel C, and Lagged Depression Indicator in Panel D are controlled. Models also include missing binary indicators for each of the control variables. 
Table 7: Exploring Pathways Through Which Combat Exposure Affects Migraine Headache

\section{Panel A: Active Duty Sample}

Combat Zone with Firefight

Overseas Non-combat Service

Service Exclusively in the U.S.

Trouble Staying Asleep

Trouble Falling Asleep

Cohen Perceived Stress Scale

PTSD

Injured

Killed or Believed Killed Someone

Observations

R-squared

$\delta_{\text {injured }}-\delta_{\text {overseas nc }}=0$ ? [p-value on F-test $]$

902
0.279
$0.111^{* *}[0.03]$

\section{Panel B: Army Sample}

Combat Zone with Firefight

Overseas Non-combat Service

Service Exclusively in the U.S.

Trouble Staying Asleep

Trouble Falling Asleep

Cohen Perceived Stress Scale

PTSD

Injured

Killed or Believed Killed Someone

Observations

R-squared

$\begin{array}{cc}0.140 * & 0.133 * \\ (0.072) & (0.074) \\ 0.048 & 0.053 \\ (0.082) & (0.088) \\ 0.052 & 0.053 \\ (0.072) & (0.069) \\ & -0.026 \\ & (0.051) \\ & 0.073 \\ & (0.053)\end{array}$

$\delta_{\text {injured }}-\delta_{\text {overseas nc }}=0$ ? [p-value on F-test $] \quad 0.092[0.32]$

$$
\begin{array}{cc}
0.104 * * * & 0.099 * * * \\
(0.036) & (0.035) \\
-0.007 & -0.009 \\
(0.040) & (0.038) \\
0.028 & 0.037 \\
(0.028) & (0.026) \\
& 0.031 \\
& (0.028) \\
& 0.057 * * \\
& (0.027)
\end{array}
$$
$0.107 * * *$
$(0.040)$
0.031
(0.027)

$0.087 * *$

$0.086 * *$

(0.035) (0.034)

(0.036)

0.002

(0.038)

0.041

(0.026)

$(0.039)$

0.040

(0.028)
0.091
$(0.061)$
$-0.004$
(0.040)
0.034
(0.027)

0.055

(0.057)

$-0.001$

(0.038)

0.047 *

(0.027)

0.018

(0.027)

$0.054 * *$

(0.027)

$-0.004$

$-0.002$

(0.005)

$0.130 * * *$
$(0.049)$

$0.176^{* *}$

(0.072)

902
0.306

902
0.294 $0.108^{* * *}[0.02]$

$0.116^{* * *}[0.02]$

902
0.305
$0.85^{*}[0.07]$

902
0.305 $0.85^{*}[0.07]$

902
0.307
$0.84^{*}[0.08]$

(0.060)

(0.005)

$0.095 *$

(0.050)

0.136*

(0.069)

0.022

(0.058) 
Appendix Table 1: Descriptive Statistics by Migraine Status, Control Variables

\begin{tabular}{|c|c|c|c|c|c|c|c|}
\hline Variable & $\begin{array}{l}\text { Active } \\
\text { Duty } \\
\text { Sample }\end{array}$ & $\begin{array}{l}\text { Overseas } \\
\text { Sample }\end{array}$ & $\begin{array}{c}\text { Exclusively } \\
\text { U.S. } \\
\text { Sample }\end{array}$ & $\begin{array}{l}\text { Combat } \\
\text { Sample }\end{array}$ & $\begin{array}{c}\text { Overseas } \\
\text { Non-Combat } \\
\text { Sample }\end{array}$ & $\begin{array}{l}\text { Combat } \\
\text { Firefight } \\
\text { Sample }\end{array}$ & $\begin{array}{c}\text { Combat } \\
\text { No-Firefight } \\
\text { Sample }\end{array}$ \\
\hline \multirow[t]{2}{*}{ Male } & 0.802 & 0.853 & 0.715 & 0.875 & 0.792 & 0.957 & 0.810 \\
\hline & $(0.399)$ & $(0.354)$ & $(0.452)$ & $(0.331)$ & $(0.407)$ & $(0.204)$ & $(0.394)$ \\
\hline \multirow[t]{2}{*}{ Height in Inches } & 69.198 & 69.462 & 68.757 & 69.570 & 69.161 & 70.184 & 69.078 \\
\hline & $(3.776)$ & $(3.772)$ & $(3.746)$ & $(3.747)$ & $(3.840)$ & $(3.578)$ & $(3.813)$ \\
\hline \multirow[t]{2}{*}{ Weight in Pounds } & 188.748 & 189.363 & 187.720 & 188.795 & 190.953 & 190.696 & 187.274 \\
\hline & $(37.800)$ & $(35.622)$ & $(41.223)$ & $(34.305)$ & $(39.149)$ & $(31.834)$ & $(36.158)$ \\
\hline \multirow[t]{2}{*}{ Missing Information: Weight in Pounds } & 0.004 & 0.005 & 0.003 & 0.005 & 0.007 & 0.005 & 0.004 \\
\hline & $(0.067)$ & $(0.073)$ & $(0.055)$ & $(0.069)$ & $(0.082)$ & $(0.074)$ & $(0.066)$ \\
\hline \multirow[t]{2}{*}{ Religion: Protestant } & 0.314 & 0.319 & 0.306 & 0.333 & 0.277 & 0.368 & 0.306 \\
\hline & $(0.464)$ & $(0.466)$ & $(0.461)$ & $(0.472)$ & $(0.449)$ & $(0.484)$ & $(0.462)$ \\
\hline \multirow[t]{2}{*}{ Religion: None, Atheist, or Agnostic Omitted } & 0.187 & 0.190 & 0.181 & 0.184 & 0.210 & 0.195 & 0.175 \\
\hline & $(0.390)$ & $(0.393)$ & $(0.386)$ & $(0.388)$ & $(0.408)$ & $(0.397)$ & $(0.381)$ \\
\hline \multirow[t]{2}{*}{ Religion: Catholic } & 0.216 & 0.224 & 0.202 & 0.232 & 0.203 & 0.227 & 0.236 \\
\hline & $(0.412)$ & $(0.417)$ & $(0.402)$ & $(0.423)$ & $(0.403)$ & $(0.420)$ & $(0.425)$ \\
\hline \multirow[t]{2}{*}{ Religion: Other Christian } & 0.209 & 0.194 & 0.234 & 0.196 & 0.189 & 0.162 & 0.223 \\
\hline & $(0.407)$ & $(0.396)$ & $(0.424)$ & $(0.397)$ & $(0.393)$ & $(0.370)$ & $(0.417)$ \\
\hline \multirow[t]{2}{*}{ Religion: Other } & 0.075 & 0.073 & 0.077 & 0.056 & 0.122 & 0.049 & 0.061 \\
\hline & $(0.263)$ & $(0.260)$ & $(0.267)$ & $(0.229)$ & $(0.328)$ & $(0.216)$ & $(0.240)$ \\
\hline \multirow[t]{2}{*}{ Missing Information:: Religion } & 0.003 & 0.005 & 0.000 & 0.005 & 0.007 & 0.000 & 0.009 \\
\hline & $(0.058)$ & $(0.073)$ & 0.000 & $(0.069)$ & $(0.082)$ & 0.000 & $(0.093)$ \\
\hline \multirow[t]{2}{*}{ Currently Married } & 0.536 & 0.559 & 0.496 & 0.560 & 0.557 & 0.578 & 0.546 \\
\hline & $(0.499)$ & $(0.497)$ & $(0.501)$ & $(0.497)$ & $(0.498)$ & $(0.495)$ & $(0.499)$ \\
\hline \multirow[t]{2}{*}{ Divorced } & 0.131 & 0.136 & 0.122 & 0.135 & 0.141 & 0.141 & 0.130 \\
\hline & $(0.337)$ & $(0.343)$ & $(0.327)$ & $(0.342)$ & $(0.349)$ & $(0.349)$ & $(0.337)$ \\
\hline \multirow[t]{2}{*}{ Had Check-up within Last Year } & 0.665 & 0.704 & 0.598 & 0.714 & 0.678 & 0.697 & 0.727 \\
\hline & $(0.472)$ & $(0.457)$ & $(0.491)$ & $(0.453)$ & $(0.469)$ & $(0.461)$ & $(0.446)$ \\
\hline \multirow[t]{2}{*}{ Missing Information: Had Check-up within Last Year } & 0.001 & 0.000 & 0.003 & 0.000 & 0.000 & 0.000 & 0.000 \\
\hline & $(0.033)$ & 0.000 & $(0.055)$ & 0.000 & 0.000 & 0.000 & 0.000 \\
\hline \multirow[t]{2}{*}{ No Health Insurance } & 0.163 & 0.120 & 0.235 & 0.107 & 0.157 & 0.121 & 0.097 \\
\hline & $(0.370)$ & $(0.326)$ & $(0.425)$ & $(0.310)$ & $(0.365)$ & $(0.327)$ & $(0.296)$ \\
\hline
\end{tabular}


Missing Information: No Health Insurance

$=1$ if 25 years old, $=0$ otherwise

$=1$ if 26 years old, $=0$ otherwise

$=1$ if 27 years old, $=0$ otherwise

$=1$ if 28 years old, $=0$ otherwise

$=1$ if 29 years old, $=0$ otherwise, omitted

$=1$ if 30 years old, $=0$ otherwise

$=1$ if 31 years old, $=0$ otherwise

$=1$ if 32 years old, $=0$ otherwise

Log of Personal Earnings

Missing Information:: Personal Earnings

Education: High School

Education: Some College or Vocational Training

Education: College Degree

Education: Graduate or Professional Degree

No Health Insurance

Missing Information:: Health Insurance

$\begin{array}{ccccccc}0.014 & 0.014 & 0.015 & 0.014 & 0.013 & 0.016 & 0.013 \\ (0.119) & (0.118) & (0.121) & (0.119) & (0.116) & (0.127) & (0.114) \\ 0.037 & 0.039 & 0.033 & 0.041 & 0.034 & 0.065 & 0.022 \\ (0.188) & (0.194) & (0.178) & (0.198) & (0.181) & (0.247) & (0.146) \\ 0.104 & 0.094 & 0.122 & 0.111 & 0.047 & 0.081 & 0.134 \\ (0.306) & (0.292) & (0.327) & (0.314) & (0.212) & (0.274) & (0.342) \\ 0.126 & 0.117 & 0.142 & 0.123 & 0.101 & 0.124 & 0.121 \\ (0.333) & (0.322) & (0.350) & (0.328) & (0.302) & (0.331) & (0.327) \\ 0.191 & 0.191 & 0.190 & 0.192 & 0.188 & 0.205 & 0.182 \\ (0.393) & (0.394) & (0.393) & (0.395) & (0.392) & (0.405) & (0.387) \\ 0.212 & 0.214 & 0.208 & 0.207 & 0.235 & 0.211 & 0.204 \\ (0.409) & (0.411) & (0.406) & (0.405) & (0.425) & (0.409) & (0.403) \\ 0.173 & 0.181 & 0.160 & 0.180 & 0.181 & 0.162 & 0.195 \\ (0.378) & (0.385) & (0.367) & (0.385) & (0.387) & (0.370) & (0.397) \\ 0.142 & 0.150 & 0.128 & 0.130 & 0.208 & 0.130 & 0.130 \\ (0.349) & (0.358) & (0.334) & (0.337) & (0.407) & (0.337) & (0.337) \\ 0.016 & 0.014 & 0.018 & 0.017 & 0.007 & 0.022 & 0.013 \\ (0.124) & (0.118) & (0.132) & (0.129) & (0.082) & (0.146) & (0.114) \\ 10.000 & 10.156 & 9.734 & 10.252 & 9.882 & 10.306 & 10.208 \\ (2.150) & (1.953) & (2.429) & (1.779) & (2.366) & (1.719) & (1.829) \\ 0.030 & 0.025 & 0.039 & 0.019 & 0.040 & 0.011 & 0.026 \\ (0.171) & (0.156) & (0.193) & (0.138) & (0.197) & (0.104) & (0.159) \\ 0.163 & 0.149 & 0.187 & 0.147 & 0.154 & 0.168 & 0.130 \\ (0.370) & (0.356) & (0.390) & (0.354) & (0.363) & (0.375) & (0.337) \\ 0.659 & 0.671 & 0.638 & 0.671 & 0.671 & 0.670 & 0.671 \\ (0.475) & (0.470) & (0.481) & (0.471) & (0.471) & (0.471) & (0.471) \\ 0.146 & 0.150 & 0.140 & 0.164 & 0.114 & 0.135 & 0.186 \\ (0.354) & (0.358) & (0.347) & (0.370) & (0.319) & (0.343) & (0.390) \\ 0.023 & 0.023 & 0.024 & 0.017 & 0.040 & 0.022 & 0.013 \\ (0.151) & (0.150) & (0.153) & (0.129) & (0.197) & (0.146) & (0.114) \\ 0.163 & 0.120 & 0.235 & 0.107 & 0.157 & 0.121 & 0.097 \\ (0.370) & (0.326) & (0.425) & (0.310) & (0.365) & (0.327) & (0.296) \\ 0.014 & 0.014 & 0.015 & 0.014 & 0.013 & 0.016 & 0.013\end{array}$


Picture Vocabulary Test Score

Missing Information:: Picture Vocabulary Test Score

Log of Parental Income Wave 1

Missing Information: Parental Income

Parent are Never Married

Parent are Married

Parent are Divorced, Separated or Widowed

Missing Information:: Parents' Marital Status

Biological Mother's Education: Less than High School

Biological Mother's Education: High School

Biological Mother's Education: Some College

Biological Mother's Education: College or More

Biological Mother's Education: Not Known

Missing Information: Biological Mother's Education

Months Served in the Military

Rank: Specialist/Corporal

$\begin{array}{ccccccc}(0.119) & (0.118) & (0.121) & (0.119) & (0.116) & (0.127) & (0.114) \\ 103.499 & 103.436 & 103.601 & 103.524 & 103.203 & 103.526 & 103.522 \\ (12.907) & (13.104) & (12.599) & (13.437) & (12.214) & (14.759) & (12.244) \\ 0.062 & 0.071 & 0.048 & 0.082 & 0.040 & 0.054 & 0.104 \\ (0.241) & (0.257) & (0.213) & (0.274) & (0.197) & (0.227) & (0.306) \\ 3.548 & 3.574 & 3.509 & 3.614 & 3.462 & 3.648 & 3.585 \\ (0.755) & (0.715) & (0.813) & (0.687) & (0.783) & (0.640) & (0.725) \\ 0.230 & 0.258 & 0.181 & 0.252 & 0.275 & 0.232 & 0.268 \\ (0.421) & (0.438) & (0.386) & (0.435) & (0.448) & (0.424) & (0.444) \\ 0.047 & 0.045 & 0.049 & 0.047 & 0.039 & 0.043 & 0.051 \\ (0.211) & (0.208) & (0.217) & (0.212) & (0.195) & (0.204) & (0.220) \\ 0.707 & 0.717 & 0.692 & 0.717 & 0.719 & 0.710 & 0.722 \\ (0.455) & (0.451) & (0.463) & (0.451) & (0.451) & (0.455) & (0.449) \\ 0.246 & 0.238 & 0.259 & 0.236 & 0.242 & 0.247 & 0.227 \\ (0.431) & (0.426) & (0.439) & (0.425) & (0.430) & (0.433) & (0.420) \\ 0.121 & 0.136 & 0.095 & 0.135 & 0.141 & 0.124 & 0.143 \\ (0.326) & (0.343) & (0.294) & (0.342) & (0.349) & (0.331) & (0.351) \\ 0.139 & 0.131 & 0.153 & 0.122 & 0.155 & 0.130 & 0.115 \\ (0.346) & (0.338) & (0.360) & (0.328) & (0.364) & (0.338) & (0.320) \\ 0.343 & 0.346 & 0.338 & 0.342 & 0.358 & 0.310 & 0.367 \\ (0.475) & (0.476) & (0.474) & (0.475) & (0.481) & (0.464) & (0.483) \\ 0.214 & 0.224 & 0.198 & 0.227 & 0.216 & 0.234 & 0.221 \\ (0.410) & (0.417) & (0.399) & (0.419) & (0.413) & (0.424) & (0.416) \\ 0.264 & 0.269 & 0.255 & 0.271 & 0.264 & 0.304 & 0.243 \\ (0.441) & (0.444) & (0.436) & (0.445) & (0.442) & (0.461) & (0.430) \\ 0.040 & 0.031 & 0.057 & 0.039 & 0.007 & 0.022 & 0.053 \\ (0.197) & (0.172) & (0.232) & (0.194) & (0.082) & (0.146) & (0.225) \\ 0.011 & 0.012 & 0.009 & 0.014 & 0.007 & 0.005 & 0.022 \\ (0.105) & (0.111) & (0.094) & (0.119) & (0.082) & (0.074) & (0.146) \\ 56.177 & 69.628 & 33.626 & 73.125 & 59.866 & 72.481 & 73.641 \\ (36.694) & (33.724) & (29.787) & (34.491) & (29.461) & (34.060) & (34.897) \\ 0.320 & 0.338 & 0.291 & 0.310 & 0.416 & 0.303 & 0.316 \\ (0.467) & (0.474) & (0.455) & (0.463) & (0.495) & (0.461) & (0.466) \\ & & & & & & \end{array}$


Rank: Sergeant

Rank: Staff Sergeant

Rank: First Class Sergeant or Higher

Served in the Army

Service Exclusively in After-September 11

1 or More Enemy Firefights

1 to 3 Enemy Firefights

4 to 19 Enemy Firefights

20 or More Enemy Firefights

$\begin{array}{ccccccc}0.275 & 0.368 & 0.119 & 0.385 & 0.322 & 0.400 & 0.372 \\ (0.447) & (0.483) & (0.324) & (0.487) & (0.469) & (0.491) & (0.485) \\ 0.104 & 0.149 & 0.030 & 0.171 & 0.087 & 0.178 & 0.165 \\ (0.306) & (0.356) & (0.170) & (0.377) & (0.283) & (0.384) & (0.372) \\ 0.081 & 0.087 & 0.071 & 0.103 & 0.040 & 0.103 & 0.104 \\ (0.273) & (0.282) & (0.258) & (0.305) & (0.197) & (0.304) & (0.306) \\ 0.398 & 0.418 & 0.365 & 0.452 & 0.322 & 0.541 & 0.381 \\ (0.490) & (0.494) & (0.482) & (0.498) & (0.469) & (0.500) & (0.487) \\ 0.238 & 0.234 & 0.246 & 0.260 & 0.161 & 0.287 & 0.238 \\ (0.426) & (0.424) & (0.432) & (0.439) & (0.369) & (0.453) & (0.427) \\ 0.445 & 0.445 & . & 0.445 & . & 1.000 & 0.000 \\ (0.498) & (0.498) & (.) & (0.498) & (.) & 0.000 & 0.000 \\ 0.166 & 0.166 & . & 0.166 & . & 0.373 & 0.000 \\ (0.372) & (0.372) & (.) & (0.372) & (.) & (0.485) & 0.000 \\ 0.132 & 0.132 & . & 0.132 & . & 0.297 & 0.000 \\ (0.339) & (0.339) & (.) & (0.339) & (.) & (0.458) & 0.000 \\ 0.147 & 0.147 & . & 0.147 & . & 0.330 & 0.000 \\ (0.354) & (0.354) & (.) & (0.354) & (.) & (0.471) & 0.000\end{array}$

Observations

$902 \quad 565$

337

416

149

185

231

Standard deviations are in parentheses. Unweighted means are generated using Waves I and IV of the National Longitudinal Study of Adolescent Health. 


\begin{tabular}{|c|c|c|c|}
\hline Dependent Variable & $\begin{array}{c}\text { (1) } \\
\text { Combat } \\
\text { vs. } \\
\text { Non- } \\
\text { Combat } \\
\end{array}$ & $\begin{array}{c}(2) \\
\text { Combat } \\
\text { Firefight } \\
\text { vs. } \\
\text { Combat } \\
\text { Non-Firefight } \\
\end{array}$ & $\begin{array}{c}\text { (3) } \\
\text { Combat } \\
\text { Firefight } \\
\text { vs. } \\
\text { Non- } \\
\text { Combat } \\
\end{array}$ \\
\hline Wave 1: Health is Excellent & $\begin{array}{c}0.067 \\
(0.122)\end{array}$ & $\begin{array}{l}-0.006 \\
(0.238)\end{array}$ & $\begin{array}{c}0.091 \\
(0.274)\end{array}$ \\
\hline Wave 1: Health is Poor & $\begin{array}{l}-0.018 \\
(0.290)\end{array}$ & $\begin{array}{l}-0.446 \\
(0.449)\end{array}$ & $\begin{array}{l}-0.822 \\
(0.849)\end{array}$ \\
\hline Height in Inches & $\begin{array}{c}0.020 \\
(0.025)\end{array}$ & $\begin{array}{c}0.028 \\
(0.040)\end{array}$ & $\begin{array}{c}0.016 \\
(0.064)\end{array}$ \\
\hline Weight in Pounds & $\begin{array}{l}-0.002 \\
(0.002)\end{array}$ & $\begin{array}{l}-0.001 \\
(0.003)\end{array}$ & $\begin{array}{l}-0.007 \\
(0.015)\end{array}$ \\
\hline Religion: Protestant & $\begin{array}{c}0.086 \\
(0.210)\end{array}$ & $\begin{array}{l}-0.015 \\
(0.308)\end{array}$ & $\begin{array}{c}0.009 \\
(0.603)\end{array}$ \\
\hline Religion: Catholic & $\begin{array}{c}0.236 \\
(0.231)\end{array}$ & $\begin{array}{c}0.139 \\
(0.354)\end{array}$ & $\begin{array}{c}0.722 \\
(1.030)\end{array}$ \\
\hline Religion: Other Christian & $\begin{array}{l}-0.028 \\
(0.215)\end{array}$ & $\begin{array}{c}0.199 \\
(0.316)\end{array}$ & $\begin{array}{c}0.719 \\
(0.712)\end{array}$ \\
\hline Religion: Other & $\begin{array}{l}-0.163 \\
(0.307)\end{array}$ & $\begin{array}{c}0.206 \\
(0.441)\end{array}$ & $\begin{array}{c}0.218 \\
(0.596)\end{array}$ \\
\hline Male & $\begin{array}{l}-0.006 \\
(0.256)\end{array}$ & $\begin{array}{c}0.184 \\
(0.352)\end{array}$ & $\begin{array}{c}0.995 \\
(1.315)\end{array}$ \\
\hline Married & $\begin{array}{l}-0.107 \\
(0.141)\end{array}$ & $\begin{array}{c}0.111 \\
(0.328)\end{array}$ & $\begin{array}{l}-0.296 \\
(0.571)\end{array}$ \\
\hline Divorced & $\begin{array}{l}-0.179 \\
(0.170)\end{array}$ & $\begin{array}{l}-0.049 \\
(0.328)\end{array}$ & $\begin{array}{c}0.098 \\
(0.570)\end{array}$ \\
\hline Age in Years & $\begin{array}{c}0.861 \\
(1.230)\end{array}$ & $\begin{array}{l}-0.987 \\
(2.017)\end{array}$ & $\begin{array}{l}5.622^{*} \\
(2.882)\end{array}$ \\
\hline Age in Years Squared & $\begin{array}{l}-0.015 \\
(0.021)\end{array}$ & $\begin{array}{c}0.015 \\
(0.035)\end{array}$ & $\begin{array}{c}-0.096^{*} \\
(0.049)\end{array}$ \\
\hline Race: Black & $\begin{array}{l}-0.019 \\
(0.158)\end{array}$ & $\begin{array}{c}-0.574 * * \\
(0.254)\end{array}$ & $\begin{array}{c}0.366 \\
(0.519)\end{array}$ \\
\hline Race: Other & $\begin{array}{c}0.336 \\
(0.237)\end{array}$ & $\begin{array}{l}-0.376 \\
(0.381)\end{array}$ & $\begin{array}{c}0.740 \\
(2.099)\end{array}$ \\
\hline Race: Hispanic & $\begin{array}{l}-0.145 \\
(0.179)\end{array}$ & $\begin{array}{c}-0.671^{* *} \\
(0.322)\end{array}$ & $\begin{array}{c}0.912 \\
(1.356)\end{array}$ \\
\hline Log of Personal Earnings & $\begin{array}{c}0.015 \\
(0.035)\end{array}$ & $\begin{array}{l}-0.015 \\
(0.054)\end{array}$ & $\begin{array}{c}-0.234 * * \\
(0.111)\end{array}$ \\
\hline Education: College or More & $\begin{array}{c}0.059 \\
(0.234)\end{array}$ & $\begin{array}{c}0.307 \\
(0.292)\end{array}$ & $\begin{array}{l}-0.086 \\
(0.575)\end{array}$ \\
\hline Picture Vocabulary Test Score & $\begin{array}{c}0.001 \\
(0.006)\end{array}$ & $\begin{array}{l}-0.010 \\
(0.011)\end{array}$ & $\begin{array}{c}0.022 \\
(0.016)\end{array}$ \\
\hline
\end{tabular}




$\begin{array}{lccc}\text { Log of Parental Income } & 0.010 & -0.120 & 0.347 \\ & (0.150) & (0.252) & (0.404) \\ \text { Parents are Married } & 0.102 & -0.370 & 0.321 \\ & (0.310) & (0.512) & (0.951) \\ \text { Parents are Divorced, Separated or Widowed } & 0.048 & -0.282 & 0.608 \\ & (0.296) & (0.602) & (1.045) \\ \text { Biological Mother's Education: Some College } & 0.114 & -0.177 & 0.977 \\ \text { Biological Mother's Education: College Degree or } & (0.143) & (0.224) & (0.605) \\ \text { More } & -0.025 & 0.053 & 0.289 \\ & & & \\ \text { Had Check-up within Last Year } & (0.158) & (0.257) & (0.889) \\ & -0.087 & 0.143 & 0.351 \\ \text { No Health Insurance } & (0.097) & (0.185) & (0.399) \\ & 0.015 & -0.034 & 0.013 \\ \text { Wave I Depression } & (0.193) & (0.247) & (0.688) \\ & 0.111 & 0.307 & 0.200 \\ \text { Wave I Migraine } & (0.152) & (0.263) & (0.385) \\ \text { Wave I Sleep Problems } & 0.109 & -0.407 & 0.377 \\ & (0.235) & (0.369) & (0.612) \\ & -0.080 & -0.152 & -0.572 \\ \text { Observations } & (0.138) & (0.275) & (0.751) \\ \text { R-squared } & & & 148 \\ \end{array}$

Robust standard errors corrected for clustering on the school are in parentheses. *, **, and *** indicate statistical significance at the $10 \%, 5 \%$, and $1 \%$ levels, respectively. All models control for school fixed effects and detailed occupation indicators. Models also include missing binary indicators for each of the control variables. 
Appendix Table 3: OLS Estimates on Full Sample of Controls

\begin{tabular}{|c|c|c|c|c|c|c|c|}
\hline VARIABLES & $\begin{array}{c}(1) \\
\text { Active } \\
\text { Duty } \\
\text { Sample }\end{array}$ & $\begin{array}{c}(2) \\
\text { Army } \\
\text { Sample }\end{array}$ & $\begin{array}{c}(3) \\
\text { Non } \\
\text { Army } \\
\text { Sample }\end{array}$ & $\begin{array}{c}(4) \\
\text { Navy } \\
\text { Sample }\end{array}$ & $\begin{array}{c}(5) \\
\text { Air } \\
\text { Force } \\
\text { Sample }\end{array}$ & $\begin{array}{c}(6) \\
\text { Marine } \\
\text { Corps } \\
\text { Sample } \\
\end{array}$ & $\begin{array}{c}(7) \\
\text { Army } \\
9 / 11 \\
\text { Sample } \\
\end{array}$ \\
\hline Combat Zone with Firefight & $\begin{array}{c}0.104 * * * \\
(0.036)\end{array}$ & $\begin{array}{l}0.140^{*} \\
(0.072)\end{array}$ & $\begin{array}{c}0.076 \\
(0.051)\end{array}$ & $\begin{array}{l}-0.055 \\
(0.083)\end{array}$ & $\begin{array}{c}0.153 \\
(1.480)\end{array}$ & $\begin{array}{c}-0.006 \\
(0.144)\end{array}$ & $\begin{array}{l}0.156^{*} \\
(0.083)\end{array}$ \\
\hline Overseas Non-combat Service & $\begin{array}{l}-0.007 \\
(0.040)\end{array}$ & $\begin{array}{c}0.048 \\
(0.082)\end{array}$ & $\begin{array}{c}0.011 \\
(0.050)\end{array}$ & $\begin{array}{c}0.013 \\
(0.068)\end{array}$ & $\begin{array}{l}-0.113 \\
(1.416)\end{array}$ & $\begin{array}{l}-0.165 \\
(0.190)\end{array}$ & $\begin{array}{c}0.106 \\
(0.086)\end{array}$ \\
\hline Service Exclusively in the U.S. & $\begin{array}{c}0.028 \\
(0.028)\end{array}$ & $\begin{array}{c}0.052 \\
(0.072)\end{array}$ & $\begin{array}{c}0.045 \\
(0.047)\end{array}$ & $\begin{array}{c}0.043 \\
(0.082)\end{array}$ & $\begin{array}{l}-0.474 \\
(2.481)\end{array}$ & $\begin{array}{l}-0.196 \\
(0.221)\end{array}$ & $\begin{array}{c}0.051 \\
(0.091)\end{array}$ \\
\hline Past Service $==1 \&$ Current Service $==0$ & $\begin{array}{c}0.013 \\
(0.031)\end{array}$ & $\begin{array}{l}-0.100^{*} \\
(0.059)\end{array}$ & $\begin{array}{c}0.023 \\
(0.049)\end{array}$ & $\begin{array}{c}0.138 \\
(0.135)\end{array}$ & $\begin{array}{c}0.666 \\
(1.656)\end{array}$ & $\begin{array}{l}-0.109 \\
(0.277)\end{array}$ & $\begin{array}{l}-0.090 \\
(0.074)\end{array}$ \\
\hline Months Served in the Military & $\begin{array}{c}0.001 * * \\
(0.001)\end{array}$ & $\begin{array}{c}0.001 \\
(0.001)\end{array}$ & $\begin{array}{c}0.001 \\
(0.001)\end{array}$ & $\begin{array}{c}0.002 \\
(0.001)\end{array}$ & $\begin{array}{c}0.001 \\
(0.064)\end{array}$ & $\begin{array}{l}-0.002 \\
(0.003)\end{array}$ & $\begin{array}{c}0.000 \\
(0.001)\end{array}$ \\
\hline Rank: Specialist/Corporal & $\begin{array}{l}-0.031 \\
(0.030)\end{array}$ & $\begin{array}{l}-0.054 \\
(0.069)\end{array}$ & $\begin{array}{c}0.019 \\
(0.054)\end{array}$ & $\begin{array}{c}0.091 \\
(0.088)\end{array}$ & $\begin{array}{l}-0.678 \\
(0.482)\end{array}$ & $\begin{array}{c}0.004 \\
(0.222)\end{array}$ & $\begin{array}{l}-0.060 \\
(0.113)\end{array}$ \\
\hline Rank: Sergeant & $\begin{array}{l}-0.051 \\
(0.040)\end{array}$ & $\begin{array}{l}-0.070 \\
(0.096)\end{array}$ & $\begin{array}{l}-0.002 \\
(0.065)\end{array}$ & $\begin{array}{c}0.038 \\
(0.120)\end{array}$ & $\begin{array}{c}-0.543 \\
(1.086)\end{array}$ & $\begin{array}{c}0.071 \\
(0.167)\end{array}$ & $\begin{array}{l}-0.049 \\
(0.129)\end{array}$ \\
\hline Rank: Staff Sergeant & $\begin{array}{c}-0.113 * * \\
(0.052)\end{array}$ & $\begin{array}{c}-0.277 * * * \\
(0.105)\end{array}$ & $\begin{array}{l}-0.030 \\
(0.093)\end{array}$ & $\begin{array}{c}0.099 \\
(0.128)\end{array}$ & $\begin{array}{l}-0.577 \\
(3.208)\end{array}$ & $\begin{array}{l}-0.078 \\
(0.331)\end{array}$ & $\begin{array}{l}-0.240 \\
(0.148)\end{array}$ \\
\hline Rank: First Class Sergeant or Higher & $\begin{array}{l}-0.070 \\
(0.053)\end{array}$ & $\begin{array}{c}-0.259 * * \\
(0.119)\end{array}$ & $\begin{array}{c}0.038 \\
(0.101)\end{array}$ & $\begin{array}{c}0.016 \\
(0.174)\end{array}$ & $\begin{array}{l}-1.025 \\
(1.605)\end{array}$ & $\begin{array}{c}0.030 \\
(0.381)\end{array}$ & $\begin{array}{l}-0.234 \\
(0.167)\end{array}$ \\
\hline Service Exclusively in After-September 11 & $\begin{array}{l}-0.036 \\
(0.028)\end{array}$ & $\begin{array}{l}-0.024 \\
(0.053)\end{array}$ & $\begin{array}{c}-0.086^{*} \\
(0.050)\end{array}$ & $\begin{array}{l}-0.126 \\
(0.117)\end{array}$ & $\begin{array}{c}-0.028 \\
(1.682)\end{array}$ & $\begin{array}{l}-0.363 \\
(0.221)\end{array}$ & $\begin{array}{l}-0.005 \\
(0.064)\end{array}$ \\
\hline Male & $\begin{array}{c}-0.113^{* *} \\
(0.046)\end{array}$ & $\begin{array}{l}-0.127 \\
(0.088)\end{array}$ & $\begin{array}{l}-0.056 \\
(0.081)\end{array}$ & $\begin{array}{l}-0.108 \\
(0.089)\end{array}$ & $\begin{array}{l}-0.217 \\
(1.940)\end{array}$ & $\begin{array}{l}-0.362 \\
(0.501)\end{array}$ & $\begin{array}{l}-0.129 \\
(0.097)\end{array}$ \\
\hline Height in Inches & $\begin{array}{l}-0.002 \\
(0.005)\end{array}$ & $\begin{array}{c}0.008 \\
(0.012)\end{array}$ & $\begin{array}{l}-0.009 \\
(0.008)\end{array}$ & $\begin{array}{c}-0.012 \\
(0.009)\end{array}$ & $\begin{array}{c}0.077 \\
(0.145)\end{array}$ & $\begin{array}{l}-0.016 \\
(0.026)\end{array}$ & $\begin{array}{c}0.007 \\
(0.015)\end{array}$ \\
\hline Weight in Pounds & $\begin{array}{c}0.000 \\
(0.000)\end{array}$ & $\begin{array}{l}-0.000 \\
(0.001)\end{array}$ & $\begin{array}{c}0.001 \\
(0.001)\end{array}$ & $\begin{array}{c}0.001 \\
(0.001)\end{array}$ & $\begin{array}{l}-0.005 \\
(0.009)\end{array}$ & $\begin{array}{c}0.001 \\
(0.002)\end{array}$ & $\begin{array}{l}-0.000 \\
(0.001)\end{array}$ \\
\hline Religion: Protestant & $\begin{array}{c}0.024 \\
(0.029)\end{array}$ & $\begin{array}{c}0.090 \\
(0.073)\end{array}$ & $\begin{array}{l}-0.003 \\
(0.040)\end{array}$ & $\begin{array}{l}-0.020 \\
(0.089)\end{array}$ & $\begin{array}{l}-1.019 \\
(1.118)\end{array}$ & $\begin{array}{c}0.010 \\
(0.194)\end{array}$ & $\begin{array}{c}0.032 \\
(0.089)\end{array}$ \\
\hline Religion: Catholic & $\begin{array}{c}0.054 \\
(0.036)\end{array}$ & $\begin{array}{c}0.179 * * \\
(0.087)\end{array}$ & $\begin{array}{c}0.050 \\
(0.047)\end{array}$ & $\begin{array}{l}-0.027 \\
(0.079)\end{array}$ & $\begin{array}{l}-0.665 \\
(2.709)\end{array}$ & $\begin{array}{c}0.163 \\
(0.165)\end{array}$ & $\begin{array}{c}0.186 \\
(0.115)\end{array}$ \\
\hline Religion: Other Christian & $\begin{array}{c}0.022 \\
(0.037)\end{array}$ & $\begin{array}{c}0.061 \\
(0.069)\end{array}$ & $\begin{array}{c}0.038 \\
(0.063)\end{array}$ & $\begin{array}{l}-0.024 \\
(0.105)\end{array}$ & $\begin{array}{l}-1.114 \\
(1.937)\end{array}$ & $\begin{array}{c}0.182 \\
(0.186)\end{array}$ & $\begin{array}{c}0.007 \\
(0.100)\end{array}$ \\
\hline Religion: Other & $\begin{array}{c}0.010 \\
(0.052)\end{array}$ & $\begin{array}{l}-0.002 \\
(0.075)\end{array}$ & $\begin{array}{c}0.042 \\
(0.068)\end{array}$ & $\begin{array}{l}-0.056 \\
(0.110)\end{array}$ & $\begin{array}{l}-0.813 \\
(2.027)\end{array}$ & $\begin{array}{c}0.319 \\
(0.287)\end{array}$ & $\begin{array}{c}0.003 \\
(0.104)\end{array}$ \\
\hline Married & $\begin{array}{c}0.004 \\
(0.022)\end{array}$ & $\begin{array}{l}-0.030 \\
(0.053)\end{array}$ & $\begin{array}{l}-0.004 \\
(0.034)\end{array}$ & $\begin{array}{c}0.011 \\
(0.043)\end{array}$ & $\begin{array}{c}0.609 \\
(0.611)\end{array}$ & $\begin{array}{c}0.051 \\
(0.162)\end{array}$ & $\begin{array}{c}0.031 \\
(0.061)\end{array}$ \\
\hline Divorced & $\begin{array}{l}-0.041 \\
(0.029)\end{array}$ & $\begin{array}{l}-0.107 \\
(0.065)\end{array}$ & $\begin{array}{c}0.017 \\
(0.041)\end{array}$ & $\begin{array}{c}0.065 \\
(0.080)\end{array}$ & $\begin{array}{c}0.423 \\
(0.650)\end{array}$ & $\begin{array}{c}0.034 \\
(0.233)\end{array}$ & $\begin{array}{l}-0.107 \\
(0.082)\end{array}$ \\
\hline$=1$ if 25 years old, $=0$ otherwise & $\begin{array}{c}0.059 \\
(0.081)\end{array}$ & $\begin{array}{c}0.215 \\
(0.202)\end{array}$ & $\begin{array}{c}0.061 \\
(0.141)\end{array}$ & $\begin{array}{l}-0.096 \\
(0.239)\end{array}$ & $\begin{array}{l}-1.601 \\
(2.311)\end{array}$ & $\begin{array}{c}-0.398 \\
(0.442)\end{array}$ & $\begin{array}{c}0.147 \\
(0.218)\end{array}$ \\
\hline$=1$ if 26 years old, $=0$ otherwise & $\begin{array}{l}-0.051 \\
(0.053)\end{array}$ & $\begin{array}{l}-0.063 \\
(0.119)\end{array}$ & $\begin{array}{l}-0.059 \\
(0.084)\end{array}$ & $\begin{array}{l}-0.078 \\
(0.165)\end{array}$ & $\begin{array}{c}0.104 \\
(1.470)\end{array}$ & $\begin{array}{c}-1.550 * * * \\
(0.494)\end{array}$ & $\begin{array}{l}-0.096 \\
(0.145)\end{array}$ \\
\hline$=1$ if 27 years old, $=0$ otherwise & $\begin{array}{c}0.048 \\
(0.044)\end{array}$ & $\begin{array}{c}0.091 \\
(0.115)\end{array}$ & $\begin{array}{c}0.001 \\
(0.052)\end{array}$ & $\begin{array}{c}0.021 \\
(0.147)\end{array}$ & $\begin{array}{c}0.216 \\
(0.736)\end{array}$ & $\begin{array}{l}-0.115 \\
(0.263)\end{array}$ & $\begin{array}{c}0.086 \\
(0.108)\end{array}$ \\
\hline$=1$ if 28 years old, $=0$ otherwise & $\begin{array}{l}0.054^{*} \\
(0.028)\end{array}$ & $\begin{array}{c}0.016 \\
(0.081)\end{array}$ & $\begin{array}{c}0.031 \\
(0.054)\end{array}$ & $\begin{array}{c}0.015 \\
(0.085)\end{array}$ & $\begin{array}{l}-0.009 \\
(0.855)\end{array}$ & $\begin{array}{c}0.171 \\
(0.143)\end{array}$ & $\begin{array}{l}-0.023 \\
(0.075)\end{array}$ \\
\hline$=1$ if 30 years old, $=0$ otherwise & $\begin{array}{c}0.016 \\
(0.032)\end{array}$ & $\begin{array}{l}-0.036 \\
(0.083)\end{array}$ & $\begin{array}{l}-0.000 \\
(0.044)\end{array}$ & $\begin{array}{c}0.005 \\
(0.084)\end{array}$ & $\begin{array}{l}-0.015 \\
(0.767)\end{array}$ & $\begin{array}{l}-0.205 \\
(0.191)\end{array}$ & $\begin{array}{c}0.018 \\
(0.106)\end{array}$ \\
\hline$=1$ if 31 years old, $=0$ otherwise & 0.048 & 0.019 & 0.026 & -0.016 & 0.300 & 0.112 & -0.014 \\
\hline
\end{tabular}


$=1$ if 32 years old, $=0$ otherwise

Log of Personal Earnings

Education: Some College

Education: College

Education: Graduate or Professional Degree

No Health Insurance

Picture Vocabulary Test Score

Log of Parental Income

Parent are Married

Parent are Divorced, Separated or Widowed

Biological Mother's Education: High School

Biological Mother's Education: Some College

Biological Mother's Education: College or More

Biological Mother's Education: Not Known

Had Check-up within Last Year

Observations

R-squared

$\delta_{\text {Combat ff }}-\delta_{\text {overseas nc }}=0$ ? [p-value on F-test $]$

\begin{tabular}{|c|c|c|c|c|c|c|}
\hline$(0.038)$ & $(0.090)$ & $(0.061)$ & $(0.075)$ & $(0.848)$ & $(0.210)$ & $(0.086)$ \\
\hline 0.025 & -0.073 & -0.061 & -0.090 & & & -0.009 \\
\hline$(0.092)$ & $(0.251)$ & $(0.083)$ & $(0.152)$ & & & $(0.325)$ \\
\hline-0.011 & -0.002 & $-0.022 * * *$ & -0.030 & 0.108 & 0.005 & 0.001 \\
\hline$(0.007)$ & $(0.015)$ & $(0.008)$ & $(0.021)$ & $(1.326)$ & $(0.043)$ & $(0.017)$ \\
\hline 0.030 & $0.106 * *$ & 0.016 & 0.016 & 0.088 & 0.051 & $0.101 *$ \\
\hline$(0.026)$ & (0.049) & $(0.033)$ & $(0.073)$ & $(0.825)$ & $(0.132)$ & $(0.055)$ \\
\hline 0.003 & 0.065 & -0.001 & 0.115 & -0.060 & -0.159 & 0.083 \\
\hline$(0.041)$ & $(0.095)$ & $(0.064)$ & $(0.087)$ & $(0.801)$ & $(0.275)$ & $(0.111)$ \\
\hline 0.149 & 0.176 & 0.235 & 0.140 & $1.926^{*}$ & -0.441 & 0.075 \\
\hline$(0.114)$ & $(0.133)$ & $(0.174)$ & (0.209) & (1.098) & (1.080) & $(0.185)$ \\
\hline-0.001 & 0.004 & 0.015 & -0.049 & -1.552 & $0.438 * *$ & 0.039 \\
\hline$(0.034)$ & $(0.069)$ & $(0.063)$ & $(0.110)$ & $(5.045)$ & $(0.189)$ & $(0.087)$ \\
\hline 0.001 & 0.002 & 0.001 & 0.003 & -0.002 & 0.004 & 0.003 \\
\hline$(0.001)$ & $(0.002)$ & $(0.002)$ & $(0.002)$ & $(0.037)$ & $(0.007)$ & $(0.003)$ \\
\hline 0.001 & -0.046 & -0.002 & -0.015 & -0.338 & 0.001 & -0.016 \\
\hline$(0.016)$ & $(0.037)$ & $(0.028)$ & $(0.044)$ & $(0.851)$ & $(0.134)$ & $(0.069)$ \\
\hline 0.005 & -0.170 & $0.117 *$ & 0.135 & -0.036 & -0.046 & -0.171 \\
\hline$(0.056)$ & $(0.163)$ & $(0.068)$ & $(0.112)$ & $(0.997)$ & $(0.342)$ & $(0.189)$ \\
\hline 0.047 & -0.074 & $0.129 *$ & 0.224 & 0.165 & 0.210 & -0.102 \\
\hline$(0.063)$ & $(0.165)$ & $(0.076)$ & $(0.137)$ & (1.063) & $(0.361)$ & $(0.181)$ \\
\hline-0.008 & -0.006 & 0.041 & 0.005 & -0.743 & 0.348 & -0.006 \\
\hline$(0.033)$ & $(0.101)$ & $(0.037)$ & (0.099) & $(2.572)$ & $(0.274)$ & $(0.094)$ \\
\hline 0.016 & -0.019 & 0.042 & -0.001 & -0.442 & 0.233 & -0.050 \\
\hline$(0.038)$ & $(0.106)$ & $(0.047)$ & $(0.091)$ & $(2.745)$ & $(0.253)$ & $(0.114)$ \\
\hline-0.007 & -0.071 & 0.042 & -0.001 & -0.362 & 0.250 & -0.099 \\
\hline$(0.034)$ & $(0.110)$ & $(0.043)$ & $(0.080)$ & (2.539) & $(0.264)$ & $(0.116)$ \\
\hline-0.069 & -0.047 & -0.107 & -0.171 & -0.920 & $0.651 *$ & 0.136 \\
\hline$(0.055)$ & $(0.151)$ & $(0.072)$ & $(0.232)$ & (1.874) & $(0.350)$ & $(0.166)$ \\
\hline 0.023 & -0.006 & 0.035 & -0.010 & -0.094 & $0.181 *$ & -0.017 \\
\hline$(0.024)$ & $(0.060)$ & $(0.033)$ & $(0.064)$ & $(0.991)$ & $(0.106)$ & $(0.078)$ \\
\hline 902 & 359 & 543 & 234 & 152 & 156 & 306 \\
\hline 0.279 & 0.508 & 0.390 & 0.827 & 0.990 & 0.861 & 0.565 \\
\hline $111^{* * *}[0.03]$ & $0.092[0.32]$ & $0.065[0.30]$ & $0.068[0.49]$ & $0.266[0.92]$ & $0.159[0.44]$ & $0.05[0.61]$ \\
\hline
\end{tabular}

Robust standard errors corrected for clustering on the school are in parentheses. *, **, and *** indicate statistical significance at the $10 \%, 5 \%$, and $1 \%$ levels, respectively. All models control for school fixed effects and detailed occupation indicators. Models also include missing binary indicators for each of the control variables 


\section{Appendix Table 4: Stability of the Estimated Effect of Deployment Assignment on Migraine}

Headache

\begin{tabular}{|c|c|c|c|c|c|c|c|}
\hline VARIABLES & $\begin{array}{c}\text { (1) } \\
\text { Active } \\
\text { Duty } \\
\text { Sample }\end{array}$ & $\begin{array}{c}\text { (2) } \\
\text { Army } \\
\text { Sample }\end{array}$ & $\begin{array}{c}\text { (3) } \\
\text { Non } \\
\text { Army } \\
\text { Sample }\end{array}$ & $\begin{array}{c}(4) \\
\text { Navy } \\
\text { Sample }\end{array}$ & $\begin{array}{c}\text { (5) } \\
\text { Air } \\
\text { Force } \\
\text { Sample }\end{array}$ & $\begin{array}{c}\text { (6) } \\
\text { Marine Corps } \\
\text { Sample }\end{array}$ & $\begin{array}{c}(7) \\
\text { Army } \\
9 / 11 \\
\text { Sample }\end{array}$ \\
\hline \multicolumn{8}{|c|}{ Panel A: Individual Controls (including occupation indicators) } \\
\hline Combat Zone with Firefight & $\begin{array}{c}0.105 * * * \\
(0.036)\end{array}$ & $\begin{array}{l}0.128 * \\
(0.074)\end{array}$ & $\begin{array}{c}0.079 \\
(0.052)\end{array}$ & $\begin{array}{c}0.009 \\
(0.083)\end{array}$ & $\begin{array}{c}0.234 \\
(0.153)\end{array}$ & $\begin{array}{c}0.116 \\
(0.157)\end{array}$ & $\begin{array}{c}0.143 \\
(0.090)\end{array}$ \\
\hline Overseas Non-combat Service (\%) & $\begin{array}{l}-0.007 \\
(0.039)\end{array}$ & $\begin{array}{c}0.047 \\
(0.071)\end{array}$ & $\begin{array}{c}0.009 \\
(0.043)\end{array}$ & $\begin{array}{c}-0.001 \\
(0.053)\end{array}$ & $\begin{array}{l}-0.148 \\
(0.183)\end{array}$ & $\begin{array}{c}0.031 \\
(0.191)\end{array}$ & $\begin{array}{c}0.093 \\
(0.078)\end{array}$ \\
\hline Service Exclusively in the U.S. (\%) & $\begin{array}{c}0.016 \\
(0.025)\end{array}$ & $\begin{array}{c}0.084 \\
(0.069)\end{array}$ & $\begin{array}{c}0.015 \\
(0.038)\end{array}$ & $\begin{array}{l}-0.019 \\
(0.069)\end{array}$ & $\begin{array}{c}0.064 \\
(0.093)\end{array}$ & $\begin{array}{l}-0.116 \\
(0.187)\end{array}$ & $\begin{array}{c}0.070 \\
(0.078)\end{array}$ \\
\hline Observations & 902 & 359 & 543 & 234 & 152 & 156 & 306 \\
\hline \multicolumn{8}{|c|}{ Panel B: Individual and Family Controls } \\
\hline Combat Zone with Firefight & $\begin{array}{c}0.104 * * * \\
(0.035)\end{array}$ & $\begin{array}{l}0.138 * \\
(0.072)\end{array}$ & $\begin{array}{c}0.076 \\
(0.050)\end{array}$ & $\begin{array}{c}-0.008 \\
(0.082)\end{array}$ & $\begin{array}{c}0.334 \\
(0.294)\end{array}$ & $\begin{array}{c}0.047 \\
(0.126)\end{array}$ & $\begin{array}{c}0.168 * * \\
(0.085)\end{array}$ \\
\hline Overseas Non-combat Service $(\%)$ & $\begin{array}{l}-0.009 \\
(0.040)\end{array}$ & $\begin{array}{c}0.064 \\
(0.076)\end{array}$ & $\begin{array}{c}0.006 \\
(0.048)\end{array}$ & $\begin{array}{c}-0.016 \\
(0.070)\end{array}$ & $\begin{array}{l}-0.075 \\
(0.343)\end{array}$ & $\begin{array}{l}-0.146 \\
(0.213)\end{array}$ & $\begin{array}{c}0.128 \\
(0.083)\end{array}$ \\
\hline Service Exclusively in the U.S. (\%) & $\begin{array}{c}0.016 \\
(0.025)\end{array}$ & $\begin{array}{c}0.075 \\
(0.072)\end{array}$ & $\begin{array}{c}0.020 \\
(0.038)\end{array}$ & $\begin{array}{c}-0.012 \\
(0.075)\end{array}$ & $\begin{array}{c}-0.071 \\
(0.166)\end{array}$ & $\begin{array}{c}-0.217 \\
(0.218)\end{array}$ & $\begin{array}{c}0.087 \\
(0.077)\end{array}$ \\
\hline Observations & 902 & 359 & 543 & 234 & 152 & 156 & 306 \\
\hline \multicolumn{8}{|c|}{ Panel C: Individual, Family, and Military Controls } \\
\hline Combat Zone with Firefight & $\begin{array}{c}0.104 * * * \\
(0.036)\end{array}$ & $\begin{array}{l}0.140 * \\
(0.072)\end{array}$ & $\begin{array}{c}0.076 \\
(0.051)\end{array}$ & $\begin{array}{l}-0.055 \\
(0.083)\end{array}$ & $\begin{array}{c}0.153 \\
(1.480)\end{array}$ & $\begin{array}{l}-0.006 \\
(0.144)\end{array}$ & $\begin{array}{l}0.156 * \\
(0.083)\end{array}$ \\
\hline Overseas Non-combat Service & $\begin{array}{l}-0.007 \\
(0.040)\end{array}$ & $\begin{array}{c}0.048 \\
(0.082)\end{array}$ & $\begin{array}{c}0.011 \\
(0.050)\end{array}$ & $\begin{array}{c}0.013 \\
(0.068)\end{array}$ & $\begin{array}{l}-0.113 \\
(1.416)\end{array}$ & $\begin{array}{l}-0.165 \\
(0.190)\end{array}$ & $\begin{array}{c}0.106 \\
(0.086)\end{array}$ \\
\hline Service Exclusively in the U.S. & $\begin{array}{c}0.028 \\
(0.028)\end{array}$ & $\begin{array}{c}0.052 \\
(0.072)\end{array}$ & $\begin{array}{c}0.045 \\
(0.047)\end{array}$ & $\begin{array}{c}0.043 \\
(0.082)\end{array}$ & $\begin{array}{c}-0.474 \\
(2.481)\end{array}$ & $\begin{array}{l}-0.196 \\
(0.221)\end{array}$ & $\begin{array}{c}0.051 \\
(0.091)\end{array}$ \\
\hline Observations & 902 & 359 & 543 & 234 & 152 & 156 & 306 \\
\hline
\end{tabular}

